US Army Corps of Engineers $s_{\circledast}$

Engineer Research and

Development Center

\title{
Beneficial Use of Dredged Material with Increased Fine Sediment Content: A Case Study at Egmont Key, Florida
}

Katherine E. Brutsché, Coraggio K. Maglio, Zachary J. Tyler, Jase D. Ousley, and Ping Wang

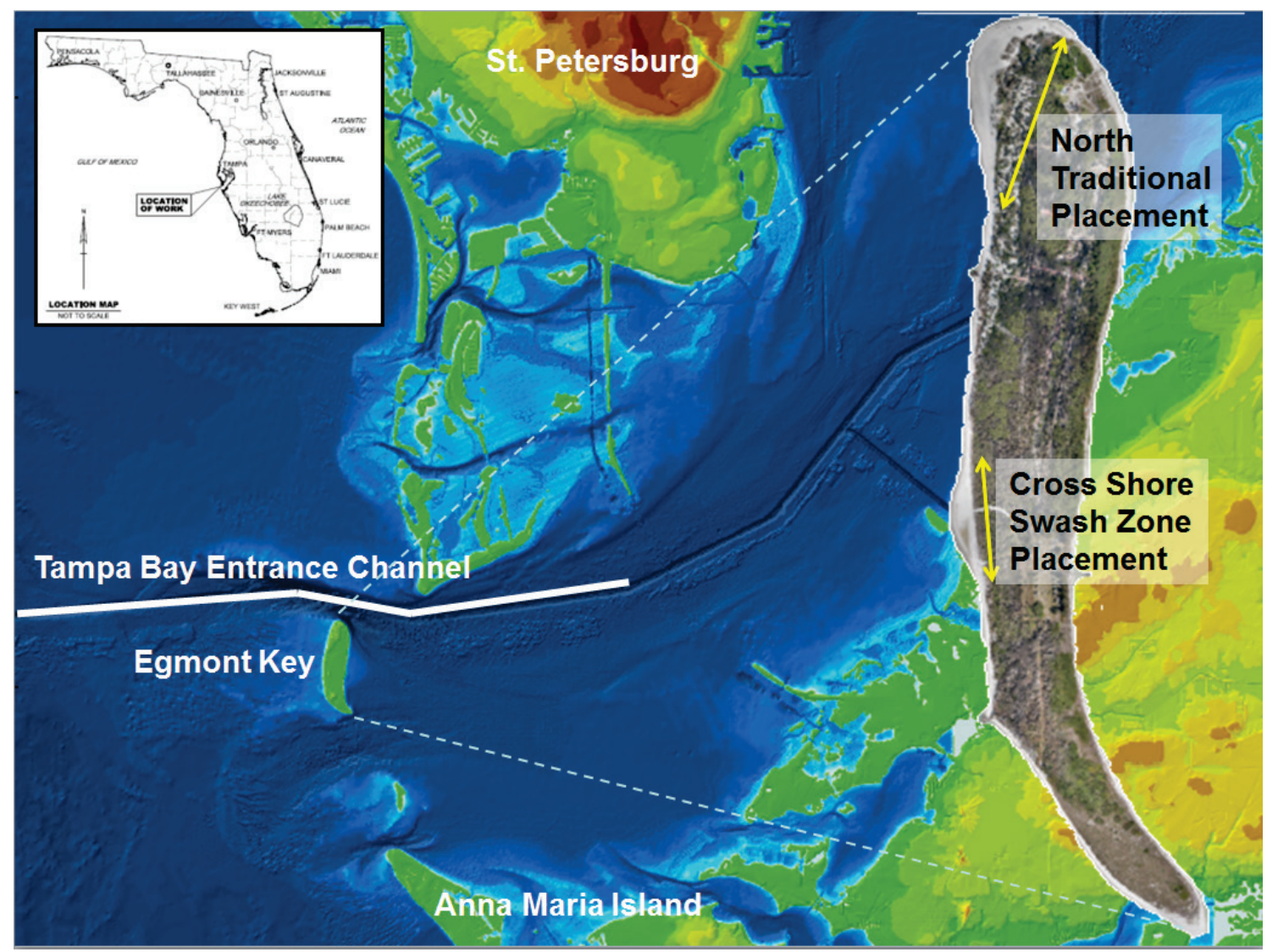


The U.S. Army Engineer Research and Development Center (ERDC) solves the nation's toughest engineering and environmental challenges. ERDC develops innovative solutions in civil and military engineering, geospatial sciences, water resources, and environmental sciences for the Army, the Department of Defense, civilian agencies, and our nation's public good. Find out more at www.erdc.usace.army.mil.

To search for other technical reports published by ERDC, visit the ERDC online library at http://acwc.sdp.sirsi.net/client/default. 


\section{Beneficial Use of Dredged Material with Increased Fine Sediment Content: A Case Study at Egmont Key, Florida}

Katherine E. Brutsché and Zachary J. Tyler

Coastal and Hydraulics Laboratory

U.S. Army Engineer Research and Development Center

3909 Halls Ferry Road

Vicksburg, MS 39180-6199

Coraggio K. Maglio

Galveston District

U.S. Army Corps of Engineers

2000 Fort Point Road

Galveston, TX 77550

Jase D. Ousley

Portland District

U.S. Army Corps of Engineers

333 SW $1^{\text {st }}$ Avenue

Portland, OR 97204

Ping Wang

University of South Florida

School of Geosciences

4202 E. Fowler Avenue

Tampa, FL 33620

Final report

Approved for public release; distribution is unlimited. 


\section{Abstract}

In November 2014, Tampa Harbor Entrance Channel was dredged, and material was placed onto Egmont Key. Although the material contained quantities of fine sediment that were greater than the State of Florida "Sand Rule" criteria, an exception was made to allow placement of the sediment directly onto the beach due to the critically eroding west shoreline of the island. Material was placed in a traditional beach nourishment template at the northern portion of the island and in a crossshore swash zone placement approximately 0.8 kilometer south of that. Beach profile surveys were collected to document morphology change of the two types of nourishments and to illustrate cross-shore location of each sediment sample. Core borings and surface sediment samples were collected and analyzed to quantify fines loss from sediment source to placement site. Although the core borings taken in the dredging area indicated an average of $20.7 \%$ fines, the surface sediment samples on the dry beach only yielded $1.9 \%$ fines on average, which is within the Florida "Sand Rule" regulation. The post-construction surface sediment samples had a similar color to the pre-construction samples.

DISCLAIMER: The contents of this report are not to be used for advertising, publication, or promotional purposes. Citation of trade names does not constitute an official endorsement or approval of the use of such commercial products. All product names and trademarks cited are the property of their respective owners. The findings of this report are not to be construed as an official Department of the Army position unless so designated by other authorized documents.

DESTROY THIS REPORT WHEN NO LONGER NEEDED. DO NOT RETURN IT TO THE ORIGINATOR. 


\section{Contents}

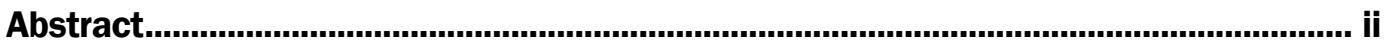

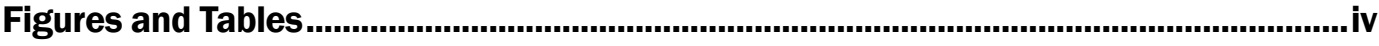

Preface .................................................................................................................... V

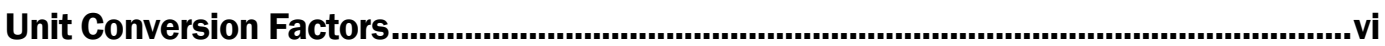

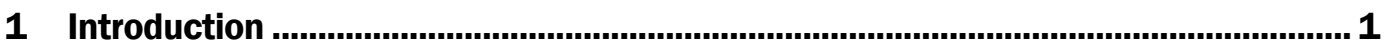

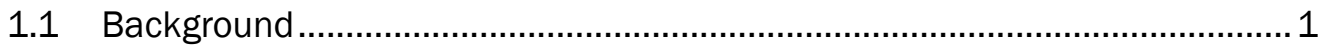

1.2 Objectives.................................................................................... 2

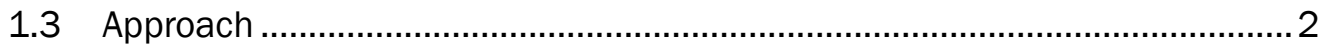

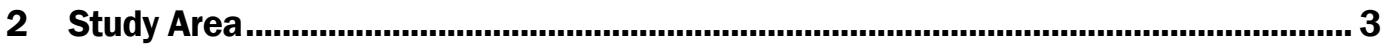

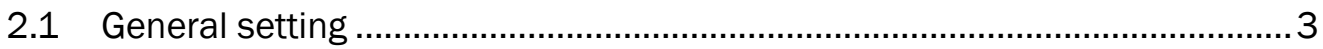

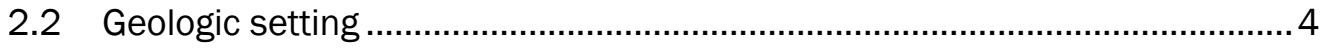

2.3 Meteorological and oceanographic conditions ........................................... 5

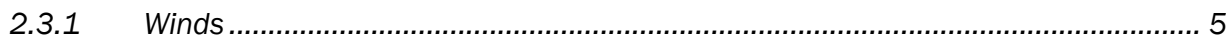

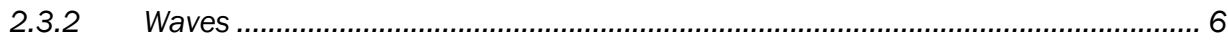

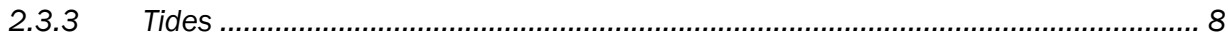

3 2014-2015 Dredging and Placement Operations ..................................................... 9

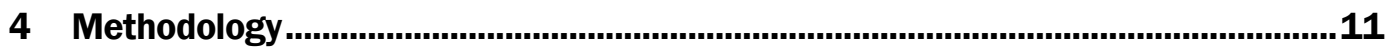

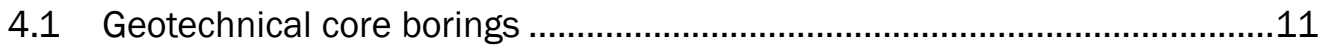

4.2 Surface sediment sampling ....................................................................

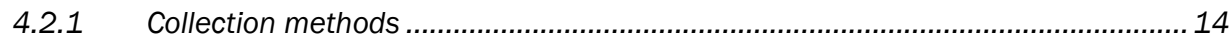

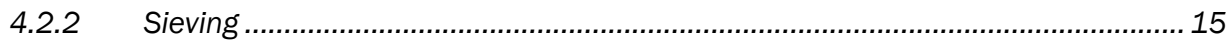

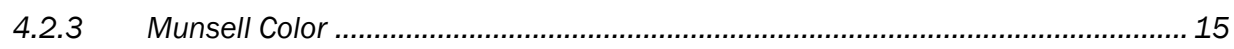

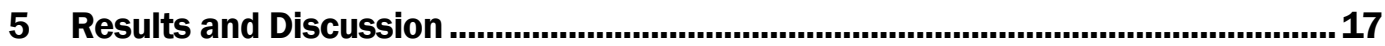

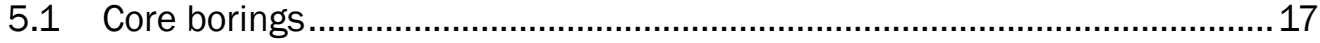

5.2 Beach profile surveys and surface sediment samples ...............................17

5.3 Core boring and sediment sample summary...........................................21

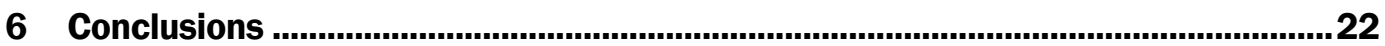

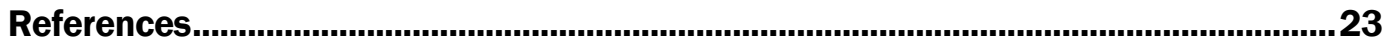




\section{Figures and Tables}

\section{Figures}

Figure 1. Egmont Key study area located at the mouth of Tampa Bay, along the west coast of Florida (upper left inset). Red " $X$ " indicates approximate location of National Oceanic and Atmospheric Administration (NOAA) Gauge 8726520.

Figure 2. Study area wind rose as observed from NOAA station 8726520 ,

St. Petersburg, FL.

Figure 3. Study area wave height, average period, peak period, and direction as observed from NDBC Station 42098, Egmont Channel.

Figure 4. Study area tidal regime as predicted for NOAA station 8726520

St. Petersburg, FL, for January 2016.

Figure 5. The Dodge Island, a GLDD hopper dredge, pumping out material to

Egmont Key on 16 December 2014.

Figure 6. Traditional beach placement at northern end of Egmont Key, Florida, 26 December 2014. (Photo courtesy of GLDD.)

Figure 7. Shore based pipeline and CSSZ placement in center of Egmont Key,

Florida, 21 February 2015. (Photo courtesy of GLDD.) 10

Figure 8. USACE Wilmington District M/V SNELL .............................................................. 11

Figure 9. All Egmont Channel and Mullet Key Channel core locations.............................. 12

Figure 10. Vibracoring apparatus deployment, Egmont Channel..................................... 13

Figure 11. Beach profile locations, Egmont Key, Florida, established 23 August

2012. Red circles indicate sediment sampling transects.

Figure 12. Profile line R-25 across the northern tip of Egmont Key in the traditional placement area.

Figure 13. Profile line R-23 across the widest part of the traditional fill area on Egmont Key.

Figure 14. Profile line R-21 across the southern taper of the traditional fill area on Egmont Key.

Figure 15. Profile line R-19 across the southern taper area of the traditional fill area on Egmont Key.

Figure 16. Profile line R-12 across the point of the CSSZ placement on Egmont Key......

Figure 17. Profile line R-11 moving south along the CSSZ placement area taper on Egmont Key.

Figure 18. Profile line R10 across the southern most portion of the CSSZ area on Egmont Key.

Figure 19. Example Munsell Color chart for reference (image from http://blog.stephens.edu/arh101glossary/?glossary=value).

\section{Tables}

Table 1. Test methods used in the analysis of core sediment samples. 


\section{Preface}

This study was conducted for the U.S. Army Corps of Engineers (USACE), under Project 456009, "Sand Enhancement from the Dredging Process." Funding was provided by the USACE, Jacksonville District; the Engineer Research and Development Center (ERDC), Dredging Operations and Environmental Research Program; and the Regional Sediment Management Program in collaboration with the University of South Florida Coastal Research Laboratory. Appreciation is expressed to the Great Lakes Dredge and Dock Company for its cooperation in field data collection efforts.

At the time of the study, the work was performed by the Coastal Engineering Branch and the Field Data Collection and Analysis Branch (CEERD-HNF) of the Navigation Division (CEERD-HN), U.S. Army Engineer Research and Development Center, Coastal and Hydraulics Laboratory (ERDC-CHL). At the time of publication, Ms. Lauren Dunkin was Chief, CEERD-HNC; Mr. William Butler was Acting Chief, CEERDHNF; Dr. Jackie Pettway was Chief, CEERD-HN; and Mr. Eddie Wiggins was the Technical Director for Navigation and Civil Works. The Deputy Director of ERDC-CHL was Mr. Jeffrey R. Eckstein, and the Director was Dr. Ty V. Wamsley.

COL Ivan P. Beckman was the Commander of ERDC, and Dr. David W. Pittman was the Director. 


\section{Unit Conversion Factors}

\begin{tabular}{|c|c|c|}
\hline Multiply & By & To Obtain \\
\hline cubic feet & 0.02831685 & cubic meters \\
\hline cubic inches & 1.6387064 E-05 & cubic meters \\
\hline cubic yards & 0.7645549 & cubic meters \\
\hline degrees Fahrenheit & $(\mathrm{F}-32) / 1.8$ & degrees Celsius \\
\hline feet & 0.3048 & meters \\
\hline inches & 0.0254 & meters \\
\hline microns & $1.0 \mathrm{E}-06$ & meters \\
\hline miles (U.S. statute) & $1,609.347$ & meters \\
\hline miles per hour & 0.44704 & meters per second \\
\hline square feet & 0.09290304 & square meters \\
\hline square inches & 6.4516 E-04 & square meters \\
\hline square miles & $2.589998 E+06$ & square meters \\
\hline square yards & 0.8361274 & square meters \\
\hline yards & 0.9144 & meters \\
\hline
\end{tabular}




\section{Introduction}

When considering borrow areas for beach and nearshore placement, coastal project managers are required to ensure that placement sediment is compatible with the native sediment. Often this means that there is a certain maximum allowable percentage of fines for a borrow area to be considered for use in beach nourishment. For example, in the State of Florida, the "Sand Rule" (Florida Administrative Code (FAC) 62B-41.007 (2)(j)(k)) allows a maximum of $10 \%$ fines (defined as sediment passing the o.063 millimeter sieve) for maintenance dredging material from navigation channels to be placed onto a beach. In current practice, the assumption is that from sediment source to placement site, there is a $0 \%$ loss of fine sediment from the dredged material. However, it has been qualitatively recognized that hopper dredges that allow overflow, or economic loading of the hopper, during operations coarsen the hopper load due to the preferential loss of fines suspended in the overflow. The study herein attempts to quantify the loss of fine sediment from the Tampa Harbor Federal navigation channel to placement site during the dredging operations at Egmont Key, Florida.

\subsection{Background}

On 19 November 2014, Great Lakes Dredge and Dock Company (GLDD) began dredging the Tampa Harbor Entrance Channel and continued maintenance dredging until early March 2015, with beach placement occurring onto Egmont Key National Wildlife Refuge. Due to the severe erosion on the westward facing beaches of Egmont Key and the fact that it is a state park, an allowance for material exceeding the Florida Administrative Code (FAC) 62B-41.007 (2)(j)(k) was made. This fines content exceedance has been accepted at Egmont Key for previous maintenance dredging projects in 2000, 2006, and 2011.

The constructed project involved beach placement of material using a traditional trapezoidal placement template methodology and a unique placement methodology referred to as "cross shore swash zone placement" (CSSZ). The traditional trapezoidal placement is characterized by a high (1.2 meter [m] North American Vertical Datum of 1988 [NAVD88]), wide ( $\sim 60 \mathrm{~m})$, and flat berm slope with tapers on the ends to transition to unfilled portions of the beach. The CSSZ placement methodology involves 
discharging material directly into the swash zone of the beach until a salient begins to form and then extending the discharge offshore until a point feature has been created in the shoreline. For this Tampa Harbor maintenance dredging event with placement onto Egmont Key, the traditional trapezoidal placement and the CSSZ placement operations occurred with a 0.8 kilometer $(\mathrm{km})$ separation between their respective nearest placement extents (Maglio et al. 2015).

\subsection{Objectives}

The overall study of the Tampa Harbor Maintenance Dredging and subsequent beneficial use of dredged material on Egmont Key included several research goals including comparing the two types of nourishments and the concerns associated with dredging material with excessive fines. The objectives of this report are to quantify fines loss from the sediment source to the placement site at Egmont Key, Florida. Findings from this study may lead to cost savings in dredging and placement by allowing the use of sediment sources that were previously thought to be incompatible. Color change of sediment is included in the discussion as that is also an important indicator of sediment compatibility and can be impacted by the presence of fines. Morphology change will be discussed only within the context of sediment sample locations along beach profiles.

\subsection{Approach}

Sediment samples were taken in Tampa Harbor Entrance Channel prior to dredging. Samples were analyzed to determine sediment grain size and quantify fines content. Following placement onto the beach, surface sediment samples were taken and analyzed for sediment grain size and fines content. Locations of surface sediment samples were recorded along beach profile transects to determine cross-shore characteristics of fines content. All samples were also analyzed for Munsell color. Channel sediment samples were compared to beach sediment samples to determine changes in fines content from dredging site to placement area. 


\section{Study Area}

\subsection{General setting}

Egmont Key is located in west-central Florida at the entrance to Tampa Bay (Figure 1). The island is approximately $3 \mathrm{~km}$ long by $0.5 \mathrm{~km}$ wide and is situated in the main tidal entrance to the bay. To the north of the island is Egmont Channel (also called Tampa Bay Entrance Channel), Tampa Bay's federally maintained shipping channel. Immediately across Egmont Channel is Mullet Key, a right-angle barrier island. To the south of Egmont Key is Southwest Passage, an unmodified channel. Farther to the south is Anna Maria Island, a barrier island. Between Egmont Key and Anna Maria Island exists an ephemeral sand body, Passage Key, whose size and subaerial extent change over time scales of months to years but generally develops in the same location. The location of Egmont Key at the mouth of Tampa Bay has rendered it historically useful, economically beneficial, and ecologically important.

Egmont Key is owned by a number of departments and resource agencies of the federal and Florida State governments. The U. S. Fish and Wildlife Service owns the southern third of the island and manages the area as a wildlife refuge. The Florida Department of Environmental Protection (FDEP) owns the northern two-thirds of the island and manages the area as a recreational and historical state park. The island's only resident is an FDEP ranger. The U.S. Coast Guard owns and operates a lighthouse on the northern end of the island. The Tampa Bay Pilots Association operates a compound that facilitates pilot operations around Tampa Bay on the eastcentral portion of the island. 
Figure 1. Egmont Key study area located at the mouth of Tampa Bay, along the west coast of Florida (upper left inset). Red " $X$ " indicates approximate location of National Oceanic and Atmospheric Administration (NOAA) Gauge 8726520.

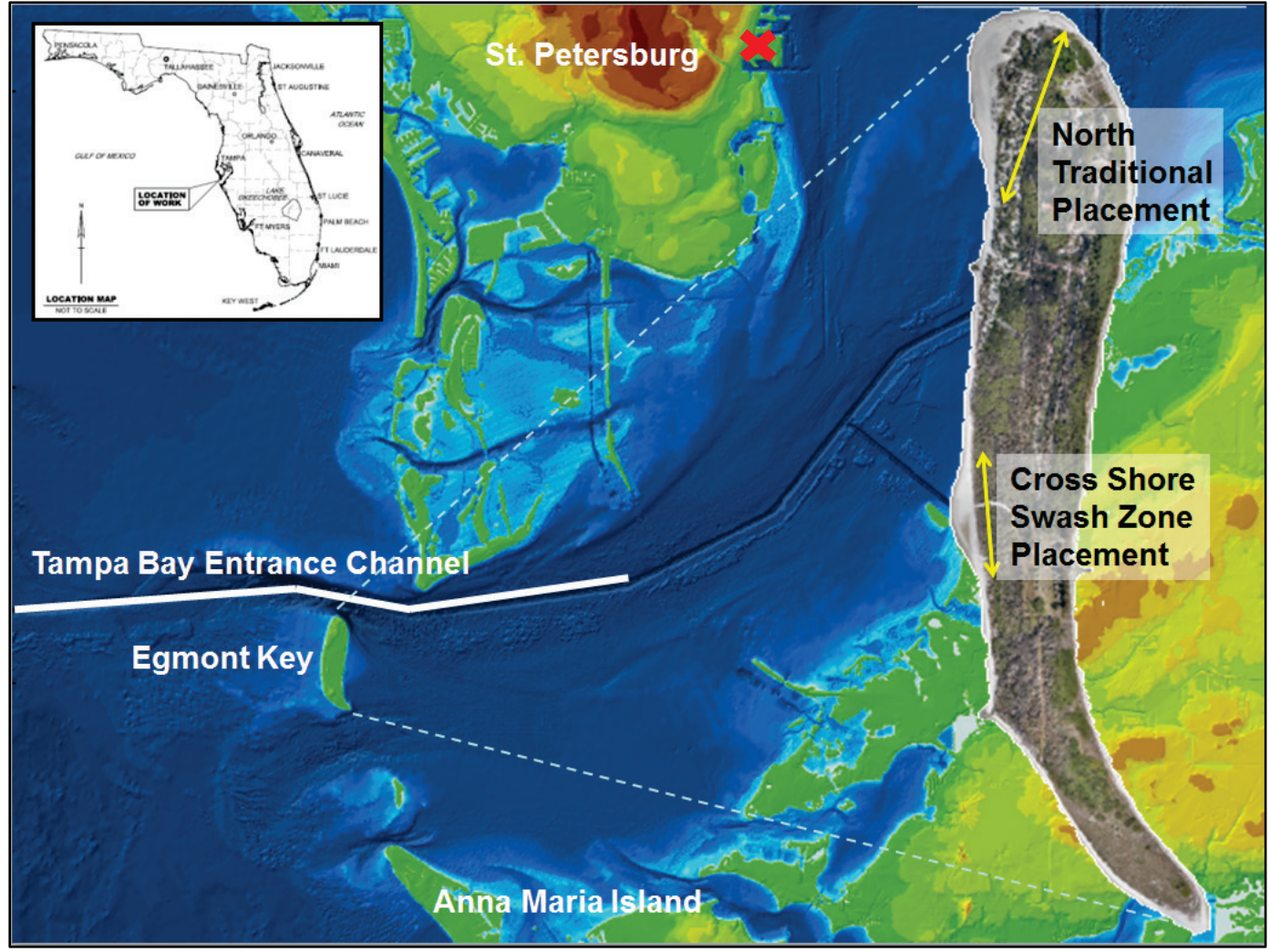

\subsection{Geologic setting}

The Egmont Key study area is located on an ancient carbonate platform that is one of the broadest and most extensively submerged continental margin systems in the world (Hine 1997). The inner west-central Florida platform is characterized by a veneer of unconsolidated sediments (approximately 3 centimeters [cm] to $3 \mathrm{~m}$ thick) overlaying an irregular base of Miocene limestone bedrock of the Arcadia Formation in the Hawthorne Group (Brooks 2003; Hine et al. 2003). The sediment veneer is mostly reworked Plio-Pleistocene quartz sand, skeletal carbonate debris with minimal tertiary limestone (Doyle and Sparks 1980). Subsequently, the region is classified as a mixed siliciclastic/carbonate regime (Ginsburg and James 1974).

Locally, the Egmont Key study area exists within the Egmont Ebb-Tidal Delta, which is a large sediment complex that extends approximately $10 \mathrm{~km}$ into the Gulf of Mexico. Located to the east of the ebb delta is Tampa Bay, a y-shaped estuary that is approximately $55 \mathrm{~km}$ long and 
$15 \mathrm{~km}$ wide. The Tampa Bay entrance between Mullet Key and Anna Maria Island is approximately $8 \mathrm{~km}$ wide and has an average depth of 7 to $8 \mathrm{~m}$ mean low water (MLW) but is naturally scoured to approximately $25 \mathrm{~m}$ below MLW in several locations within the federal navigation channel. Similar to the regional sedimentary regime, the area is characterized by a veneer of unconsolidated sediments with increased fines content on top of limestone bedrock (Ferguson and Davis 2003).

\subsection{Meteorological and oceanographic conditions}

\subsubsection{Winds}

The west-central Florida region is dominated by local wind-generated waves. Consequently, wind speed, direction, and duration are significant factors that control coastal morphodynamics. Wind speed and direction as measured from NOAA Station (8726520) at St. Petersburg, FL (Figure 2), which is $20 \mathrm{~km}$ northeast of Egmont Key, from 2000 - 2016 are summarized in Figure 2. Since the Egmont Key shoreline is oriented approximately north to south, easterly wind is directed offshore and does not have significant influence on nearshore processes. During the 16-year period, from 2000 to 2016 , an offshore wind occurs $61 \%$ of the time. While local wind-generated waves are usually the cause of wave-induced coastal changes, swell waves are not uncommon and are generally a result of the distal passage of tropical cyclones.

Winds that are directly out of the north $\left(0^{\circ}\right)$ occur $5.1 \%$ of the time. These northerly winds are associated with the passage of winter cold fronts. Winds that approach the study area out of the west are relatively evenly distributed with respect to time and are less frequent as easterly winds. 
Figure 2. Study area wind rose as observed from NOAA station 8726520 , St. Petersburg, FL.

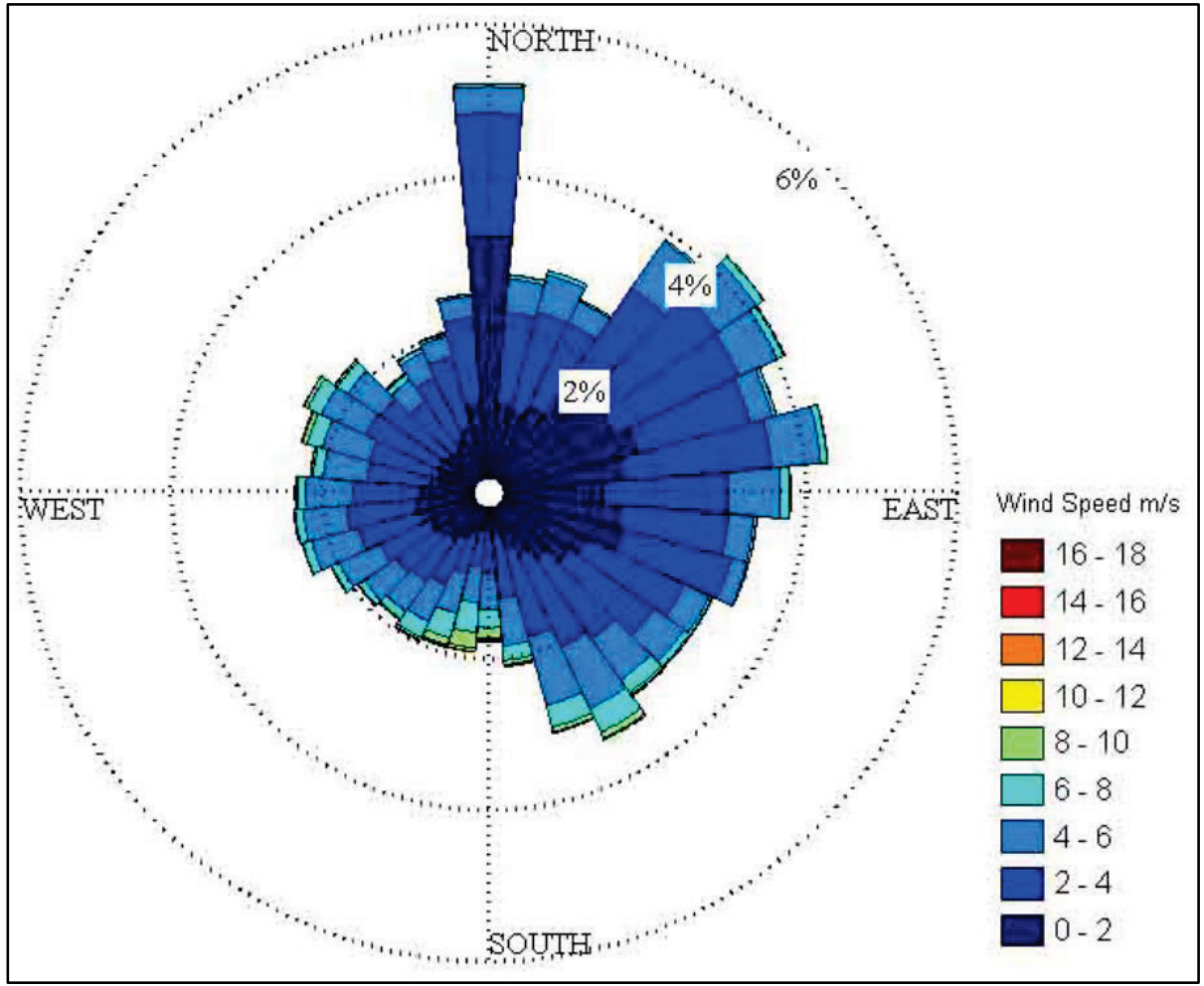

\subsubsection{Waves}

Wave height, period, and direction are the dominant factors that control nearshore morphodynamics. Wave data for study area were obtained NOAA National Data Buoy Center (NDBC) Station 42098, located $15 \mathrm{~km}$ due west of the seaward entrance to Egmont Channel. The wave gauge has been operational since June 2015, and data from June 2015 through July 2016 are presented in Figure 3. A distinct seasonal difference was observed in the wave data. During the summer months, waves are generally less than $2 \mathrm{~m}$ in height, with peak periods $\leq 8$ seconds (Figure 3 ). During the winter months, higher energy wave events associated with cold fronts occur approximately every 10 to 14 days. These passing fronts produce wave heights slightly greater than $4 \mathrm{~m}$ with average periods slightly less than 8 seconds. The largest waves have recorded peak wave period that exceed 10 seconds. 
Figure 3. Study area wave height, average period, peak period, and direction as observed from NDBC Station 42098, Egmont Channel.

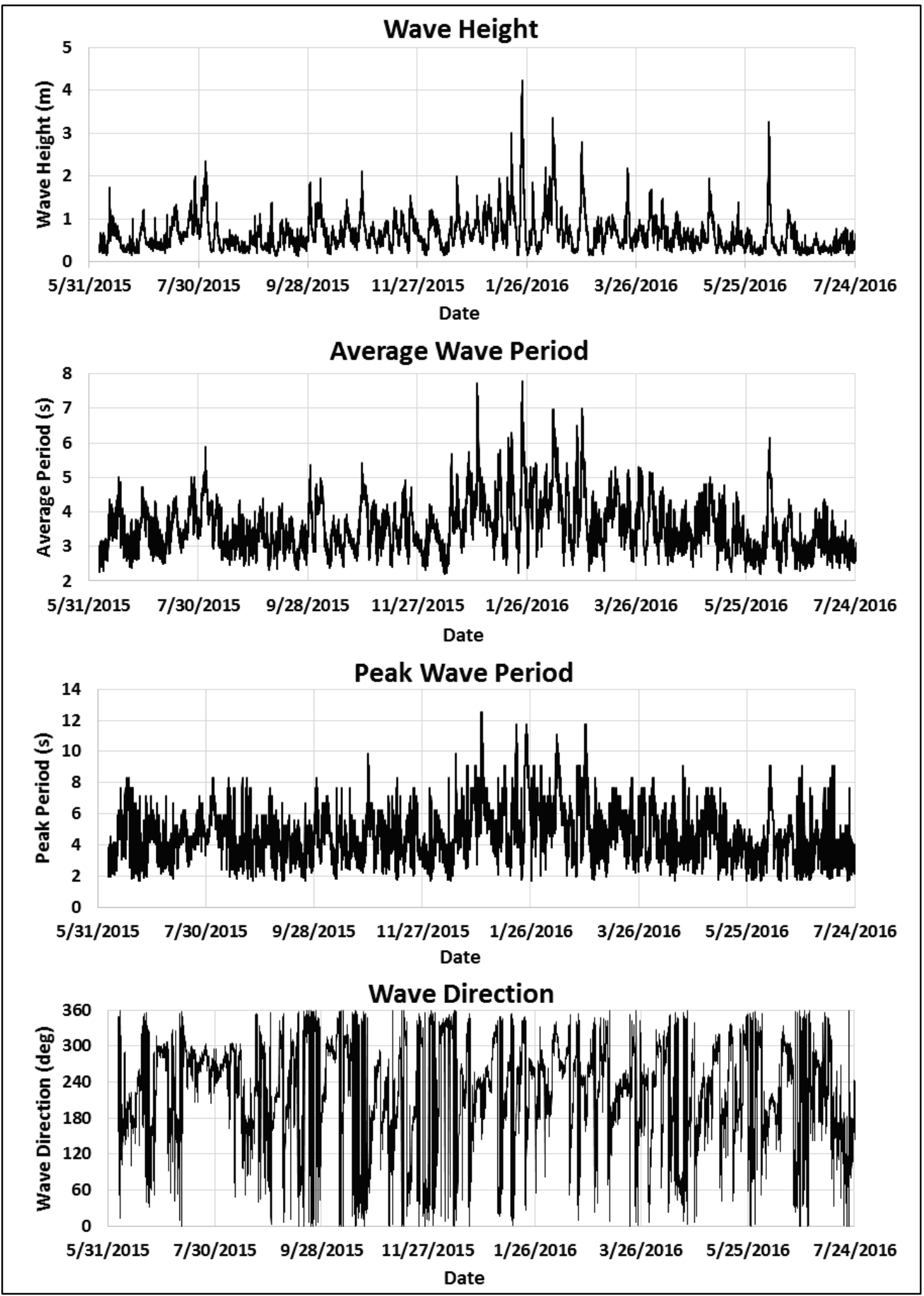




\subsubsection{Tides}

The study area experiences a mixed tide regime in that it has diurnal and semidiurnal components of unequal magnitudes. Spring tides are diurnal and have an approximate range of 0.8 to $1.2 \mathrm{~m}$. Neap tides are semidiurnal with an approximate range of 0.4 to $0.5 \mathrm{~m}$ (Wang et al. 2011). An example tidal record as observed from St. Petersburg, FL (NOAA Station 8726520) for January 2016 (Figure 4) illustrates this spring/neap tidal cycle. Tidal range in the study area is less than $2 \mathrm{~m}$ and classified as micro-tidal. Although the tidal range is relatively small, tides play an important role in the nearshore morphodynamics of the study area. This is mainly due to the large water body area $\left(1,030 \mathrm{~km}^{2}\right)$ and tidal prism $\left(6.466 \times 10^{9} \mathrm{~m}^{3}\right)$ of Tampa Bay (Galperin et al. 1991; Goodwin 1984; Lewis and Estevez 1988). The large tidal prism drives strong tidal flows through the two inlets, Egmont Channel and Southwest Passage, at both ends of Egmont Key. These tidal flows can potentially have significant influence on the morphodynamics of Egmont Key.

Figure 4. Study area tidal regime as predicted for NOAA station 8726520 St. Petersburg, FL, for January 2016.

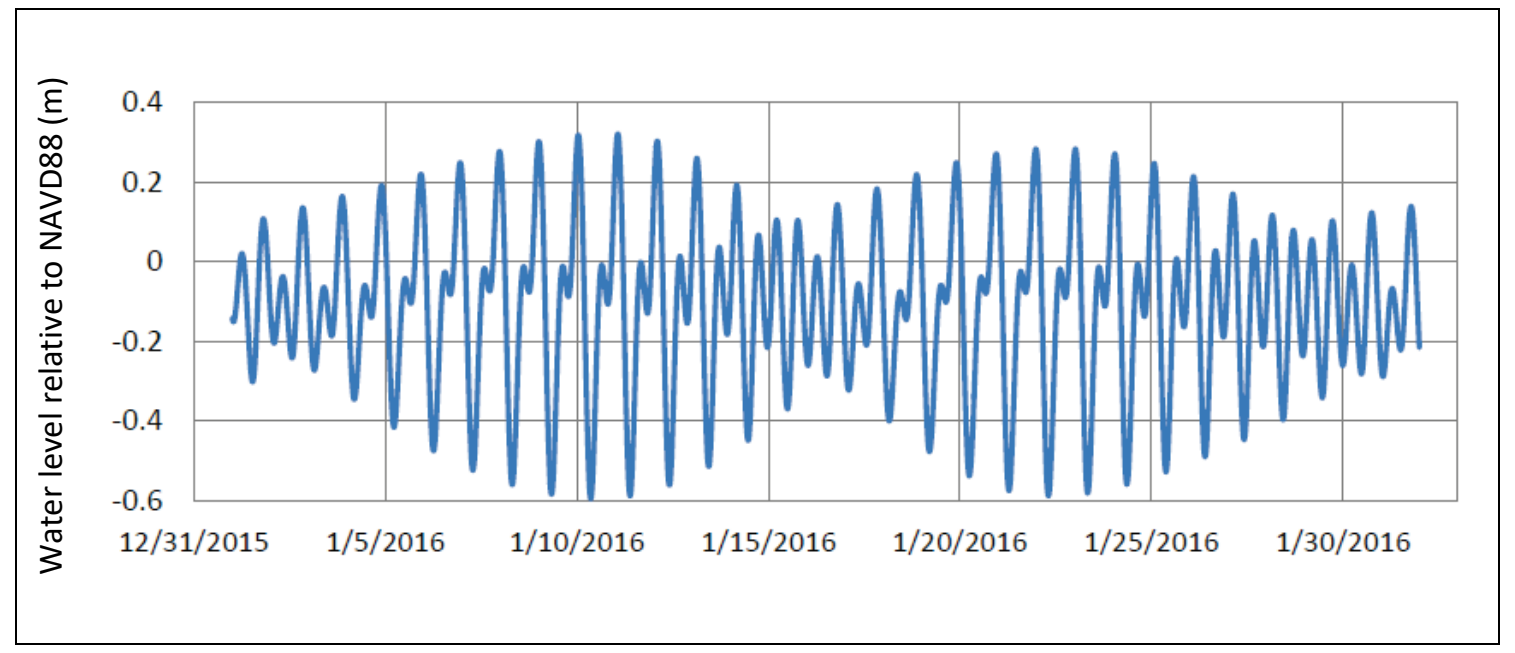




\section{2014-2015 Dredging and Placement Operations}

The 2014-2015 Tampa Harbor dredging project was conducted by the GLDD hopper dredges the Dodge Island (November and December 2014) and the Padre Island (January through March 2015). Both dredges used bow pump-out capabilities to send material to the placement areas using a pipeline (see Figure 5). Material was dredged from Tampa Harbor Entrance Channel and placed in two portions of Egmont Key, with two different types of nourishment styles. A traditional beach nourishment was constructed at the north end of the island, while a CSSZ nourishment was constructed just south of the midpoint of the island (Figure 1).

Figure 5. The Dodge Island, a GLDD hopper dredge, pumping out material to Egmont Key on 16 December 2014.

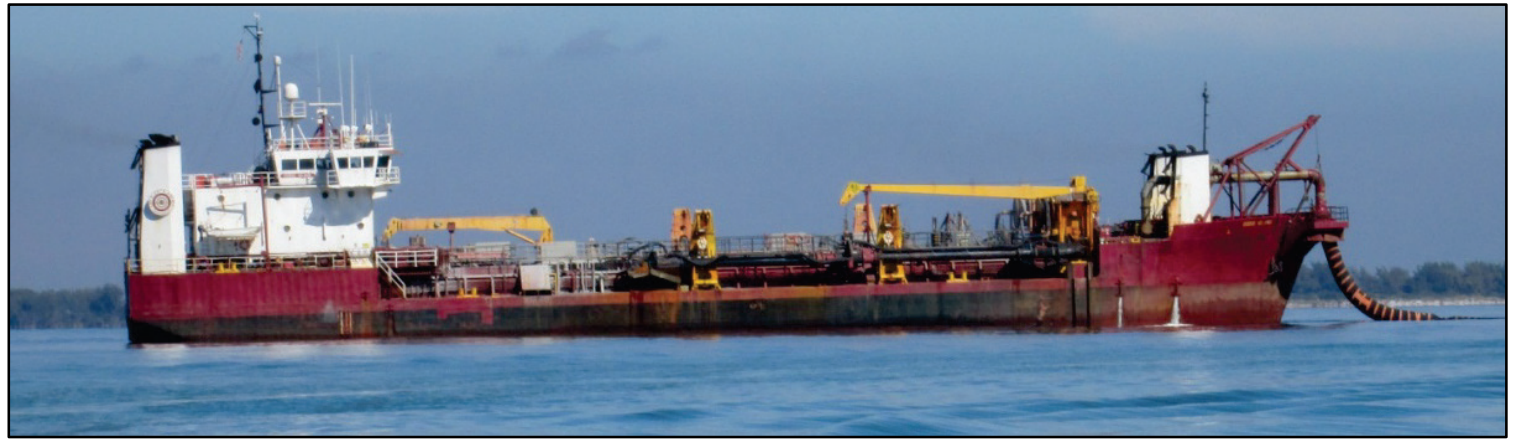

The traditional trapezoidal fill template at the northern end of Egmont Key used a Y-valve and two placement cells with longitudinal dikes with intermediate spurs to increase settlement and minimize material lost to the active swash zone, see Figure 6 . The use of this placement design with a Y-valve with two cells allows for one side to be closed down for extending outfall pipes without having to stop discharge. Placement of dredged material occurred at the north end of the island from 19 November to 28 December 2014 and then from 21 January to 5 February 2015. Total volume of this placement was approximately $244,000 \mathrm{~m}^{3}$.

Approximately $0.8 \mathrm{~km}$ south of the traditional beach nourishment, the CSSZ placement was constructed. Geomorphic features created by the CSSZ placement method were designed to function as a feeder beach to areas adjacent to the nourishment. The CSSZ placement occurred from 8 February to 6 March 2015, with a total volume of approximately $82,000 \mathrm{~m}^{3}$. Figure 7 shows the completed northern beach placement as well as the CSSZ placement being constructed. 
Figure 6. Traditional beach placement at northern end of Egmont Key, Florida, 26 December 2014. (Photo courtesy of GLDD.)

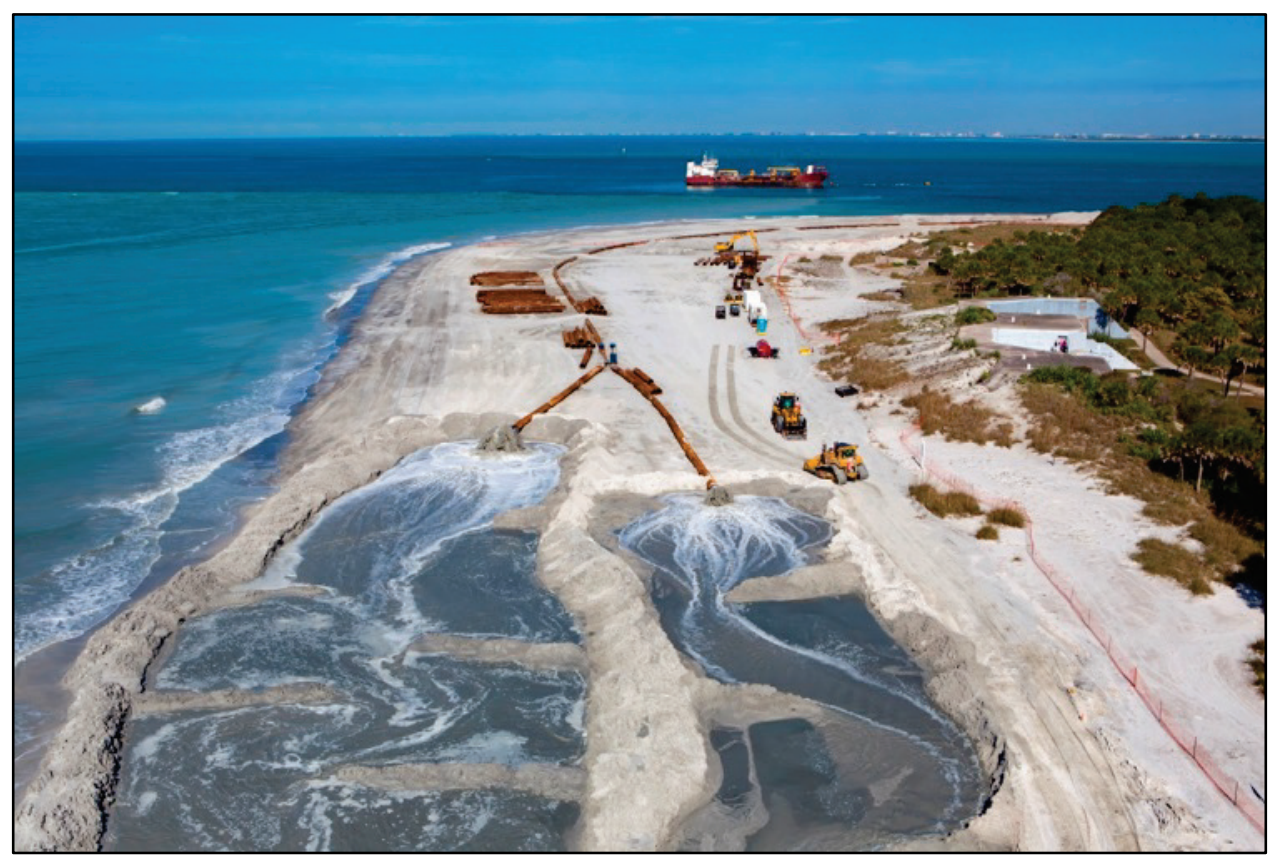

Figure 7. Shore based pipeline and CSSZ placement in center of Egmont Key, Florida, 21 February 2015. (Photo courtesy of GLDD.)

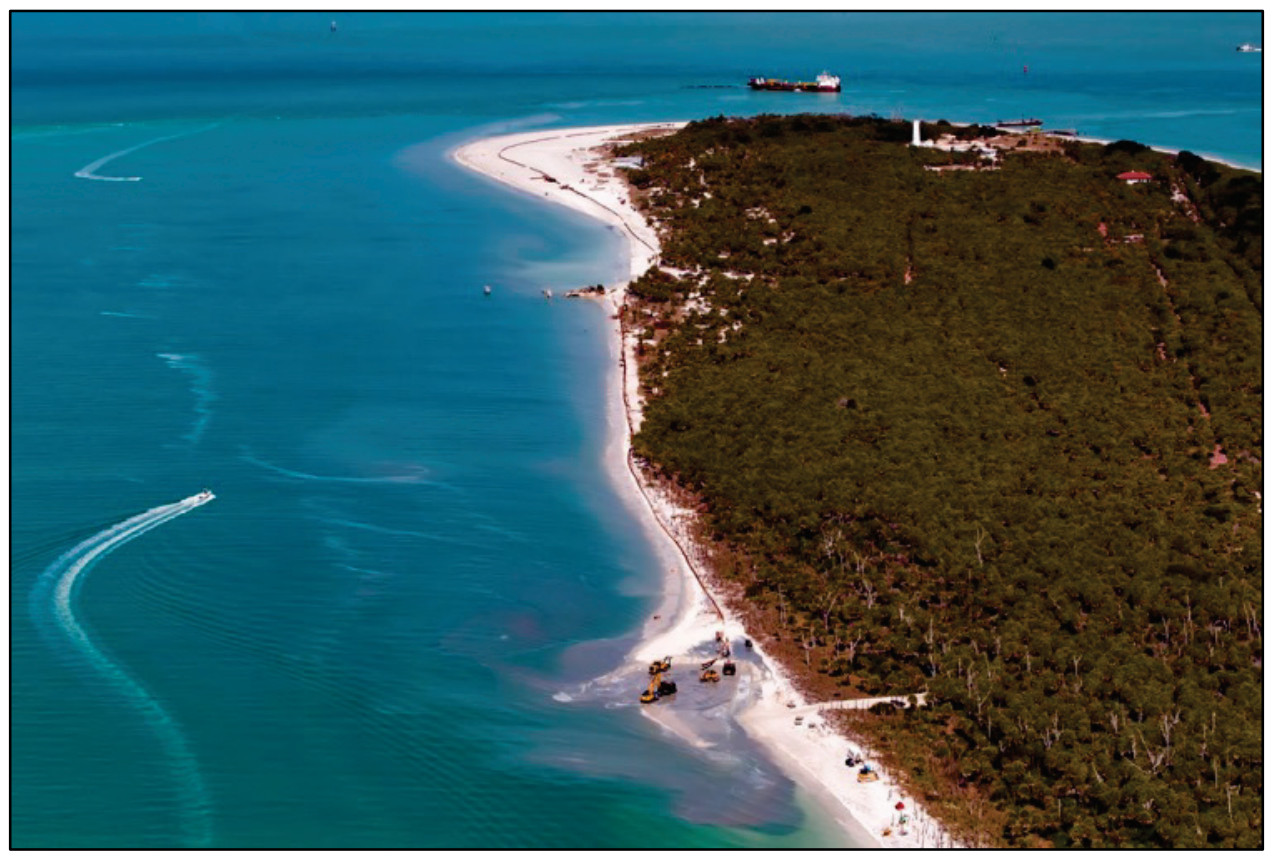




\section{Methodology}

\subsection{Geotechnical core borings}

As part of preparation for the 2014-2015 Tampa Harbor Entrance Channel Operation and Maintenance Project, the U.S. Army Corps of Engineers (USACE), Jacksonville District, collected vibracores to characterize the shoaled sediments in the dredge prism for the Egmont Key nourishment. The investigation consisted of 39 vibracore borings collected along the margins of the authorized federal navigation channels (Egmont and Mullet Key). The cores were collected to provide samples for the physical analysis of grain size, visual shell percentage, and carbonate content. Analysis of the cores was completed by the University of South Florida Coastal Research Laboratory (USF CRL).

Vibracoring was conducted by the USACE multi-purpose vessel (M/V) $S N E L L$ (Figure 8). The $S N E L L$ is approximately $32 \mathrm{~m} \times 10 \mathrm{~m}$ with a draft of $\sim 2 \mathrm{~m}$. The vessel carries a 35-ton crane that deploys the vibracoring apparatus. During the period of 2-3 April 2014, the SNELL obtained 39 cores: 34 cores from Egmont Channel Cut 1, 1 core from Egmont Channel Cut 2, and 4 cores from Mullet Key Channel (Figure 9).

Figure 8. USACE Wilmington District M/V SNELL.

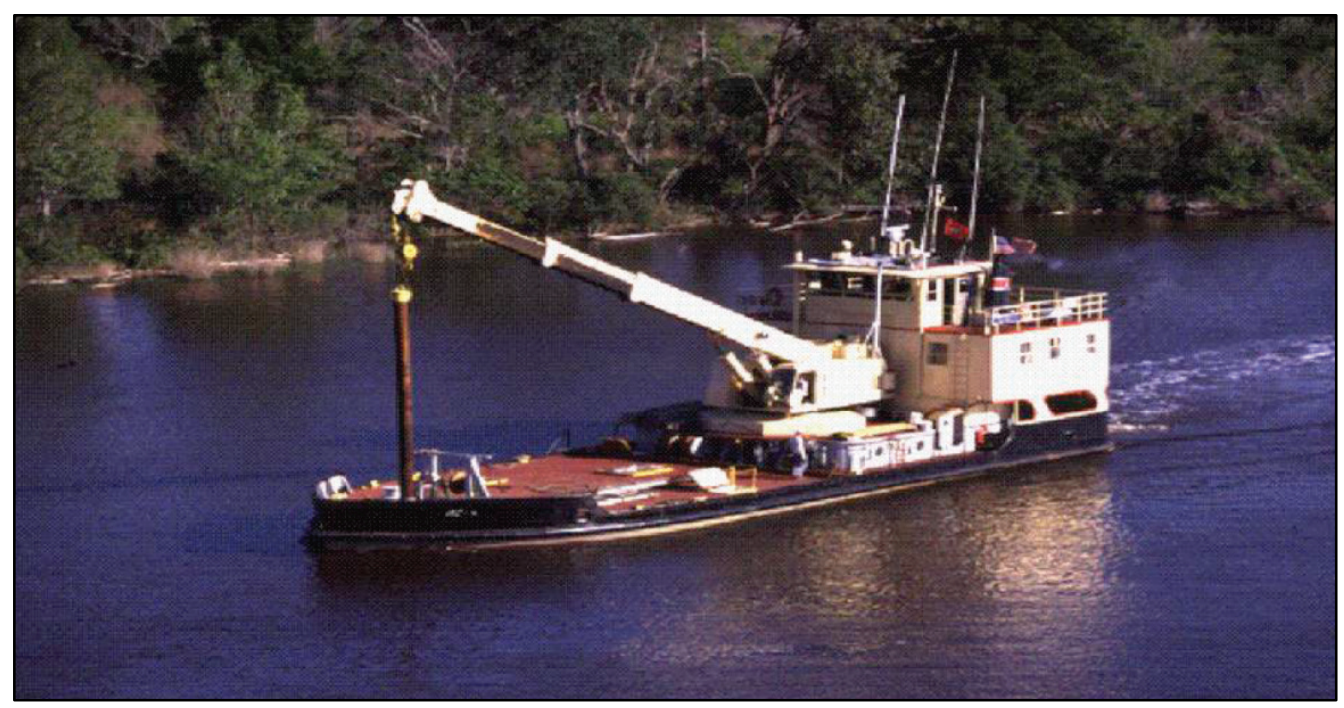


Figure 9. All Egmont Channel and Mullet Key Channel core locations.

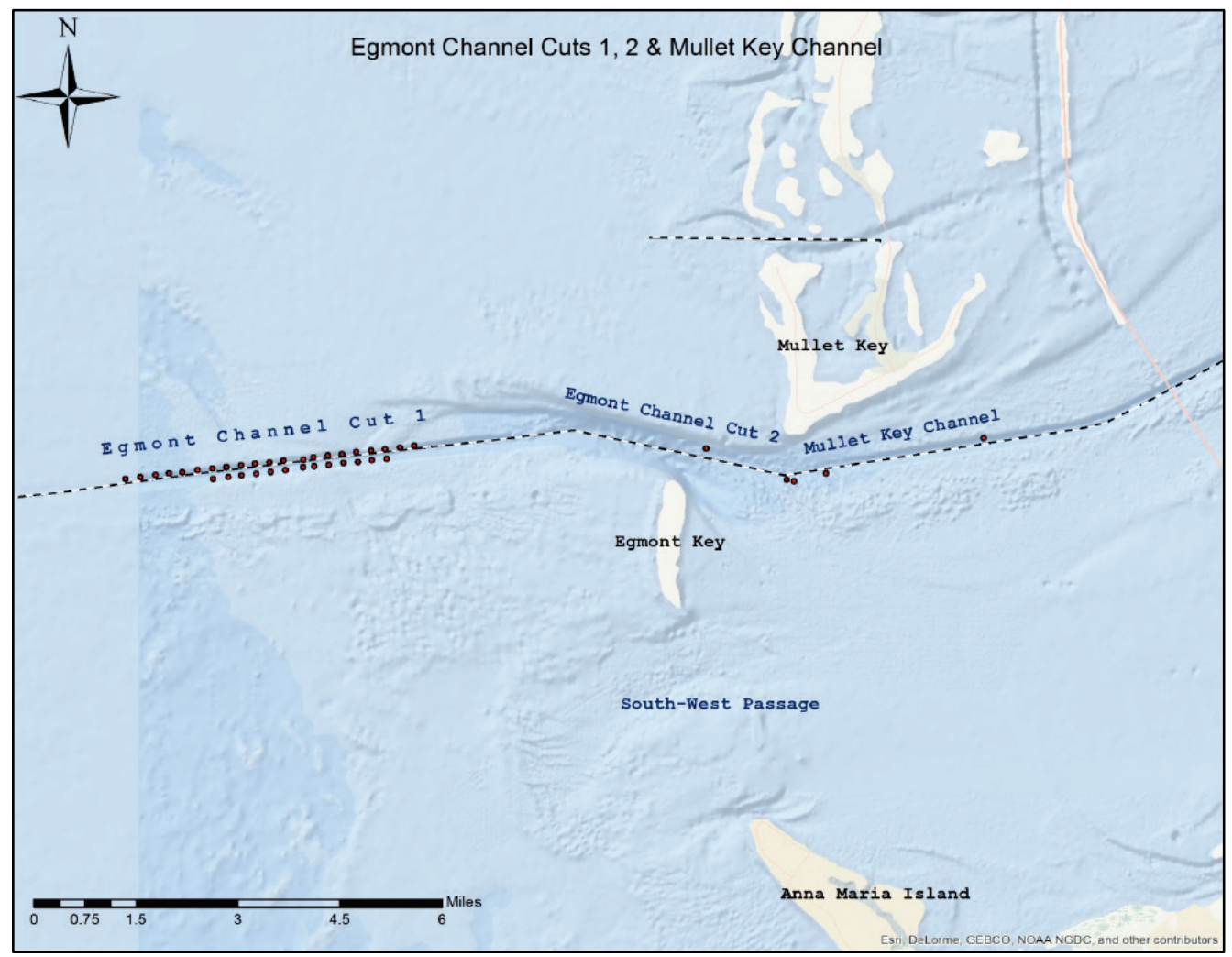

All borings were drilled using an International Construction Equipment Model 2 hydraulic vibratory driver fitted with a 4-inch outer diameter drill stem, clear plastic liner, sediment retainer, drilling shoe, and a model 50 power unit (Figure 10). Borings were sited using a Furuno NavNet $3 \mathrm{D}$ global positioning system located on the crane and linked to HYPACK ${ }^{\odot}$ with DREDGEPACK $\odot$. Elevations of the borings were determined using the horizontal position of the boring(s) projected onto the Lower Tampa Bay Examination Survey FY13. The vibracore apparatus was modified to limit the maximum depth of penetration to $1.5 \mathrm{~m}$. Sample depth was constrained so that samples captured the shoaled material within the dredging prism along with the upper portion of the channel substrate while reducing sampling below the needed strata. All borings were measured to ensure a minimum of $80 \%$ recovery. The average penetration for the borings was $1.4 \mathrm{~m}$. 
Figure 10. Vibracoring apparatus deployment, Egmont Channel.

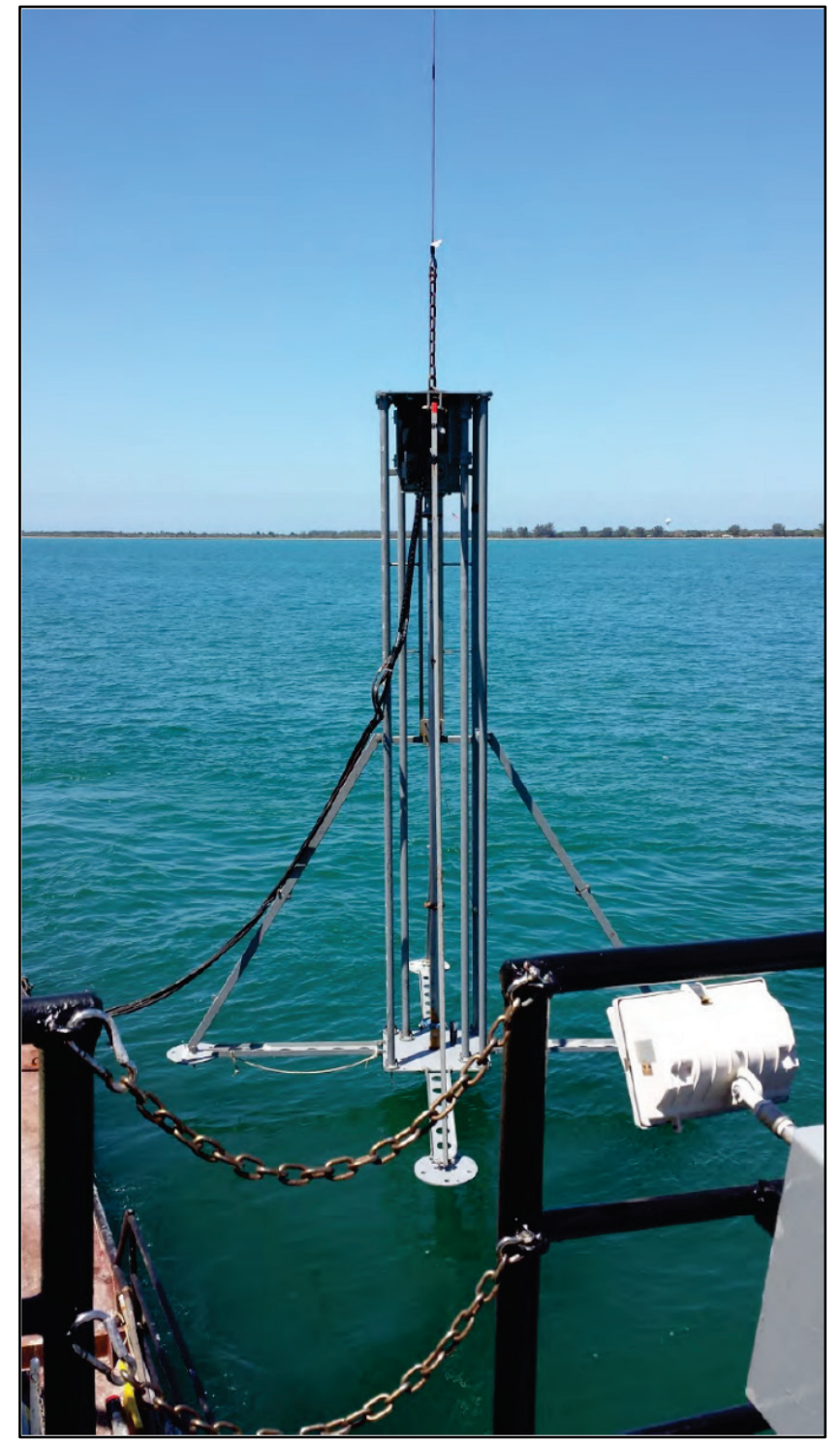

Upon delivery to the USF CRL, all cores were stood vertically. Next, any excess core pipe was cut just above the sediment surface, packed with paper towels, and recapped. The cores were then cut lengthwise in half with a circular saw using a plastic cutting blade. Once cut, each core was carefully split using metal hand scrapers. One half was immediately cleaned by scraping a level surface, photographed, wrapped in plastic, labeled and archived. The other half was set aside for visual classification and sampling and subsequently wrapped in plastic and archived as well.

All cores were visually classified in accordance with the American Society for Testing and Materials (ASTM) Standard Practice Designation D2488- 
09a. Visual shell estimates were appended to this procedure. A total of 80 samples were taken from the 39 cores following the methods presented in Table 1. Sampled layers were defined based on visual change in color and/or texture of the sediment.

Table 1. Test methods used in the analysis of core sediment samples.

\begin{tabular}{|l|l|}
\hline Test / Procedure & Method \\
\hline $\begin{array}{l}\text { Standard Practice for Description and Identification } \\
\text { of Soils (Visual - Manual Procedure) }\end{array}$ & $\mathrm{D} 2488$ \\
\hline $\begin{array}{l}\text { Grain Size Sieve Analysis (Using Sieve Sizes No. } \\
\text { 3/4", 5/8", 7/16", 5/16", 3.5, 4, 5, 7, 10, 14, 18, } \\
25,35,45,60,80,120,170,200,230)\end{array}$ & D6913 \\
\hline Munsell Color & Munsell Soil Color Charts \\
\hline Carbonate Content, Non-ASTM & Twenhofel and Tyler (1941) \\
\hline Visual Percent Shell & $\begin{array}{l}\text { Modified D2488 to include } \\
\text { visual shell estimates }\end{array}$ \\
\hline
\end{tabular}

\subsection{Surface sediment sampling}

\subsubsection{Collection methods}

To document detailed changes in morphology and locations of surface sediment samples, beach profile transects at 28 locations (Figure 11) along the Gulf-, Channel-, and Bay-facing beaches were established by the USF CRL. Horizontal and vertical survey controls (benchmarks) were established using a Real Time Kinematic Global Positioning System in August 2012. Profile spacing was approximately $120 \mathrm{~m}$, and most of the profiles were along the Gulf facing beaches. Beach profile measurement followed standard level-and-transit procedures using a Topcon GTS$240 \mathrm{NW}$ electronic total survey station and a $4 \mathrm{~m}$ prism pole. Most of the beach profiles extended at least $50 \mathrm{~m}$ seaward to the short-term depth of closure (Wang and Davis 1998). Ten beach profile surveys were conducted along the 28 transects from August 2012 to August 2015 to capture the short-term beach changes and beach nourishment evolution. For the purposes of this report, focus will remain on the preconstruction, post-construction, and 5 months post-construction (August 2015) surveys. Although outside the scope of this report, detailed information on the morphology change of the two types of nourishments can be found in Tyler (2016). 
Surface sediment samples along 11 of the 28 beach profile transects were collected using a $10 \mathrm{~cm}$ polyvinyl chloride pipe capped at one end (Figure 11). Samples were taken from the surface to a depth no more than $10 \mathrm{~cm}$. Similar to the measurement method used for beach profile surveying, the sampling scheme was based on morphology characteristics, with samples collected from the dune to the short-term depth of closure. On average, seven samples were taken from each profile with approximately half being taken on the subaerial beach and the other half from the subaqueous portion of the profile. Surface sediment samples were collected three times: pre-construction of the nourishment (September 2014), immediately post-construction (March 2015), and 5 months following construction (August 2015). Sediment characteristics at these three times were compared to examine the redistribution of different size fractions of the sediment.

\subsubsection{Sieving}

Surface sediment samples were processed and analyzed with the same procedure used for the cored channel sediments, following ASTM D6913. Sieves used for analysis ranged from the three-quarter-inch to the No. 230 sieve. Mean grain size and sorting were calculated using the Moment Method (Folk and Ward 1957).

\subsubsection{Munsell Color}

To evaluate sediment color at the placement sites, dry beach samples were collected both prior to and following construction and analyzed for Munsell Color values (Munsell 2000). Additionally, Munsell Color analysis was conducted on samples collected from the regions of the channel where the dredged material was sourced. Munsell color classifies color by hue, chroma and value. The Munsell color hue indicates the relationship of the color to red, yellow, green, blue, and purple. The Munsell color chroma relates the color strength or departure from a neutral of the same lightness. The Munsell color value ranges from 1 to 8 and relates to the darkness of the sediment; the lower the number, the darker the material. Munsell color was determined by a digital colorimeter. 
Figure 11. Beach profile locations, Egmont Key, Florida, established 23 August 2012. Red circles indicate sediment sampling transects.

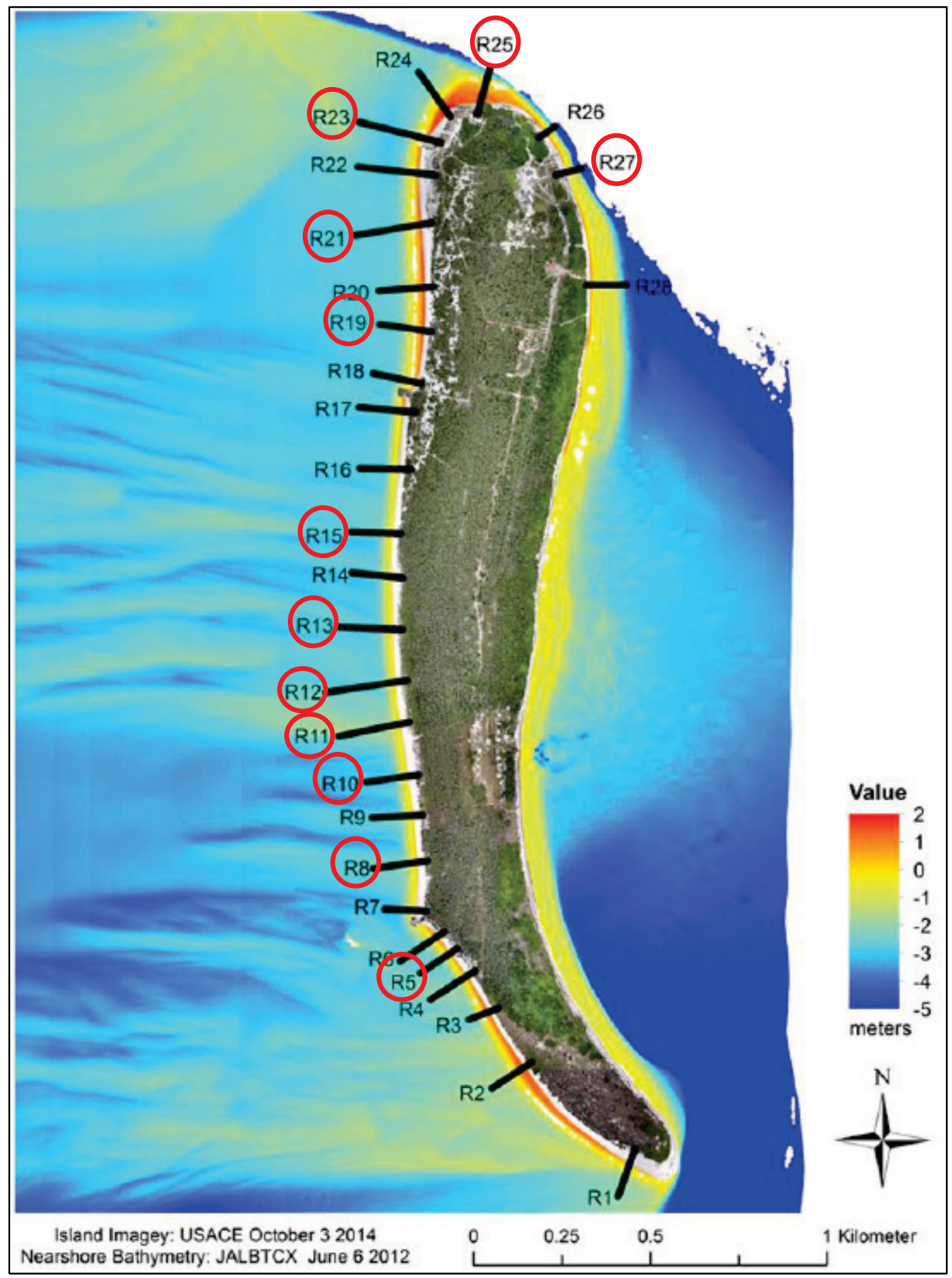




\section{Results and Discussion}

\subsection{Core borings}

USACE Jacksonville District collected 39, $1.5 \mathrm{~m}$ vibracore borings in shoaled areas of Cut 1, Cut 2, and the Mullet Key Cut in the Tampa Harbor Entrance Channel in 2014. The percentage of fines in the in situ samples ranged from $0.5 \%$ to $80.7 \%$. The average composited fines percentage was 20.7\%. Cores were also analyzed for color, and a composite Munsell Color value of 4.36 was obtained. It was assumed that the dredging process would homogenize the dredged sediment and a composite Munsell would accurately represent the in situ sediment color.

\subsection{Beach profile surveys and surface sediment samples}

The USF CRL collected cross-shore profile surveys along Egmont Key prior to construction in September 2014 and following construction in March and August 2015 (Figure 12-Figure 18). Surface sediment samples were taken along the cross shore profile lines.

Figure 12-Figure 18 indicate the percentage of fines for each of the surface sediment samples taken along the profiles. The pre-construction profiles in the traditional nourishment template contained less than $2 \%$ fines on the subaerial beach. Higher percentages of fines were typically found with distance offshore. A maximum fines content of $17.9 \%$ was measured at the toe of the foreshore along R21; however, generally the sediment samples contained less than approximately $5 \%$ fines. Immediately postconstruction in March 2015, samples on the subaerial beach contained 5\% or less of fine material. Again, the highest percentage of fines was found at the toe of the foreshore with up to $34.3 \%$ at R19 (Figure 15). This is also at the edge of the fill, which may have had an impact on the anomalous concentration of fines seen here. 
Figure 12. Profile line R-25 across the northern tip of Egmont Key in the traditional placement area.

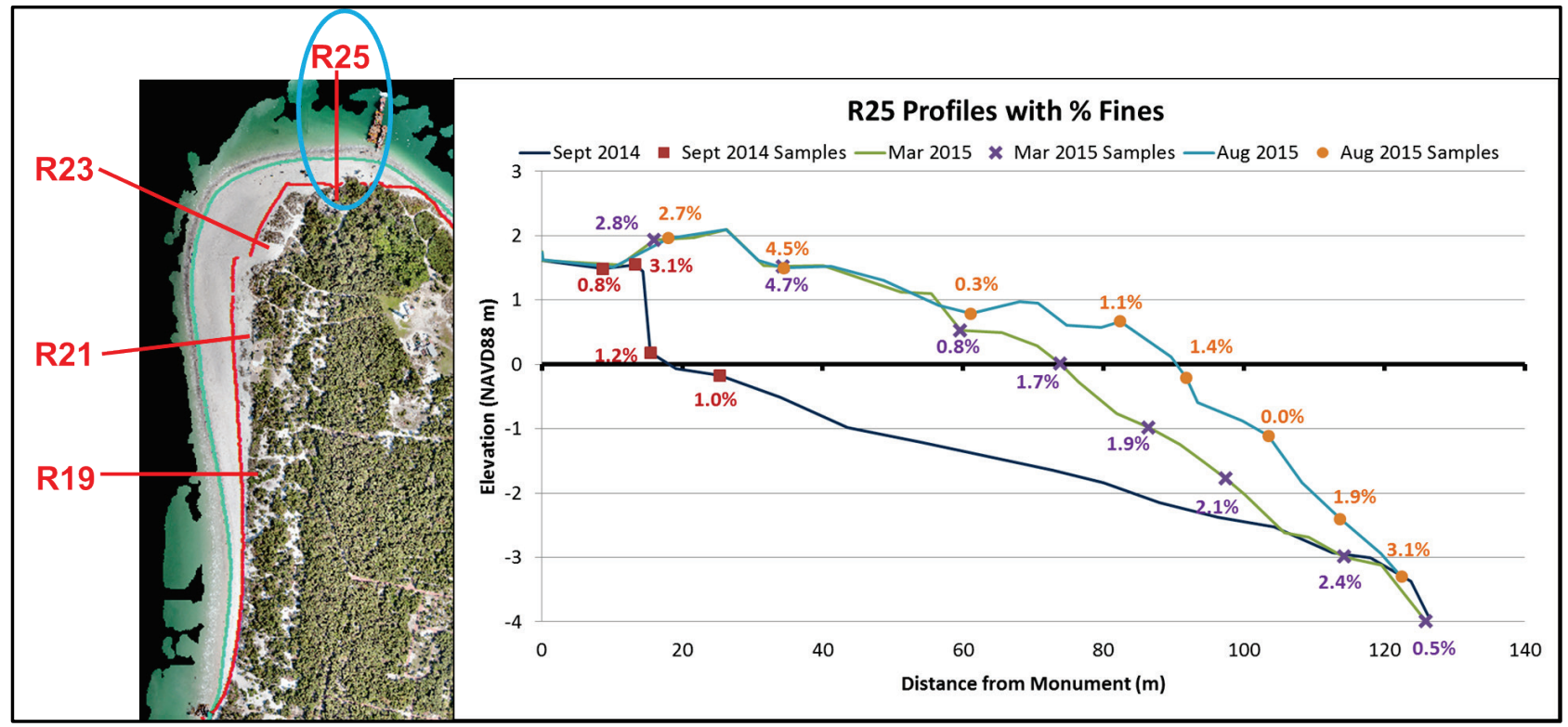

Figure 13. Profile line R-23 across the widest part of the traditional fill area on Egmont Key.

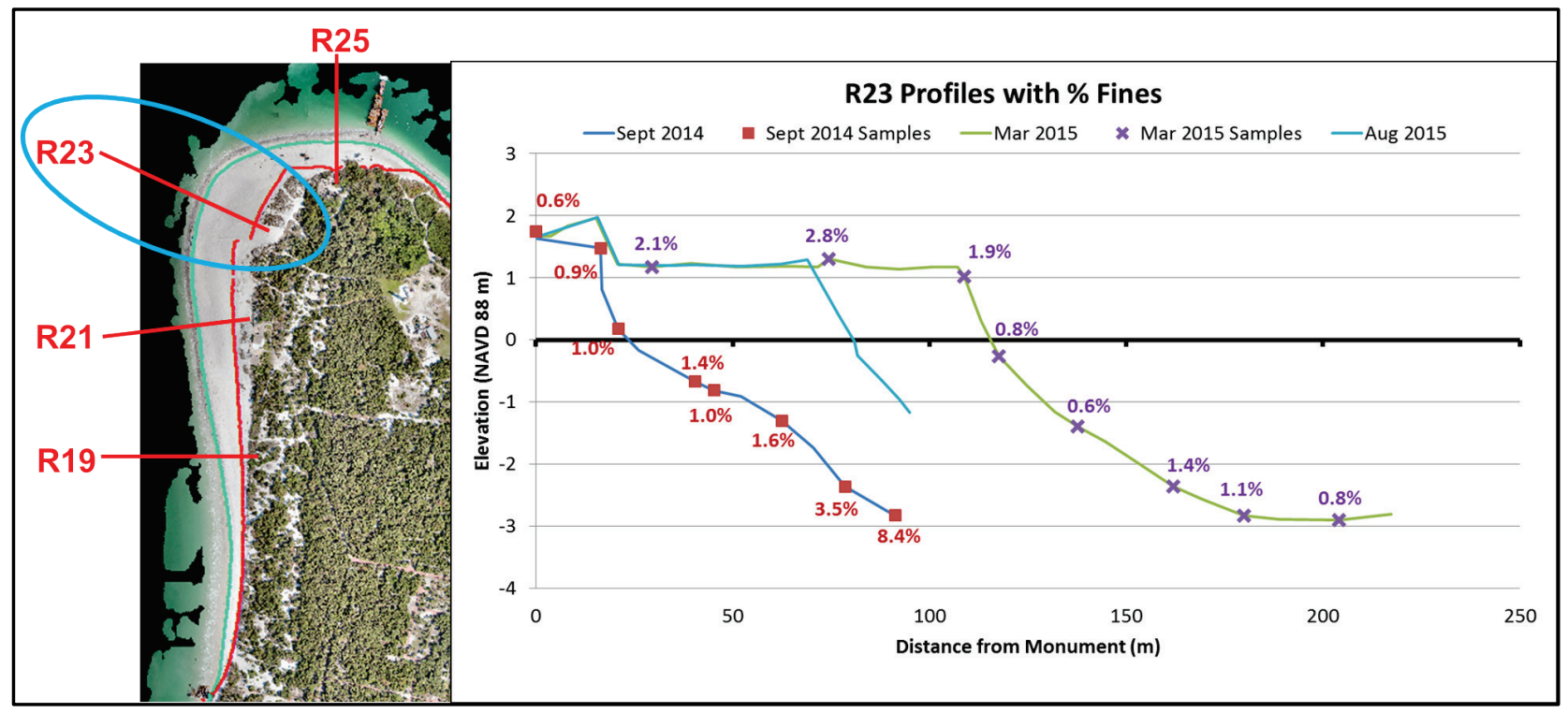


Figure 14. Profile line R-21 across the southern taper of the traditional fill area on Egmont Key.

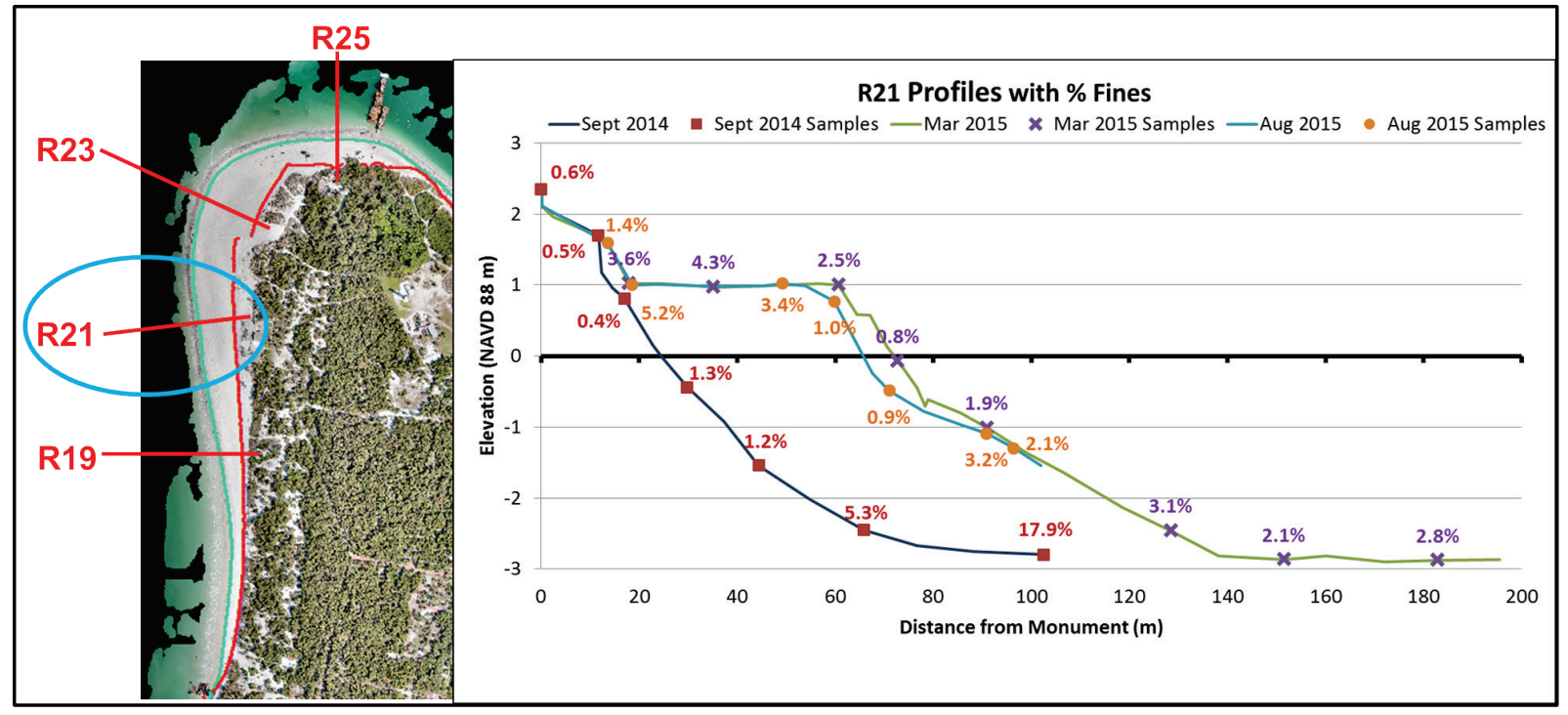

Figure 15. Profile line R-19 across the southern taper area of the traditional fill area on Egmont Key.

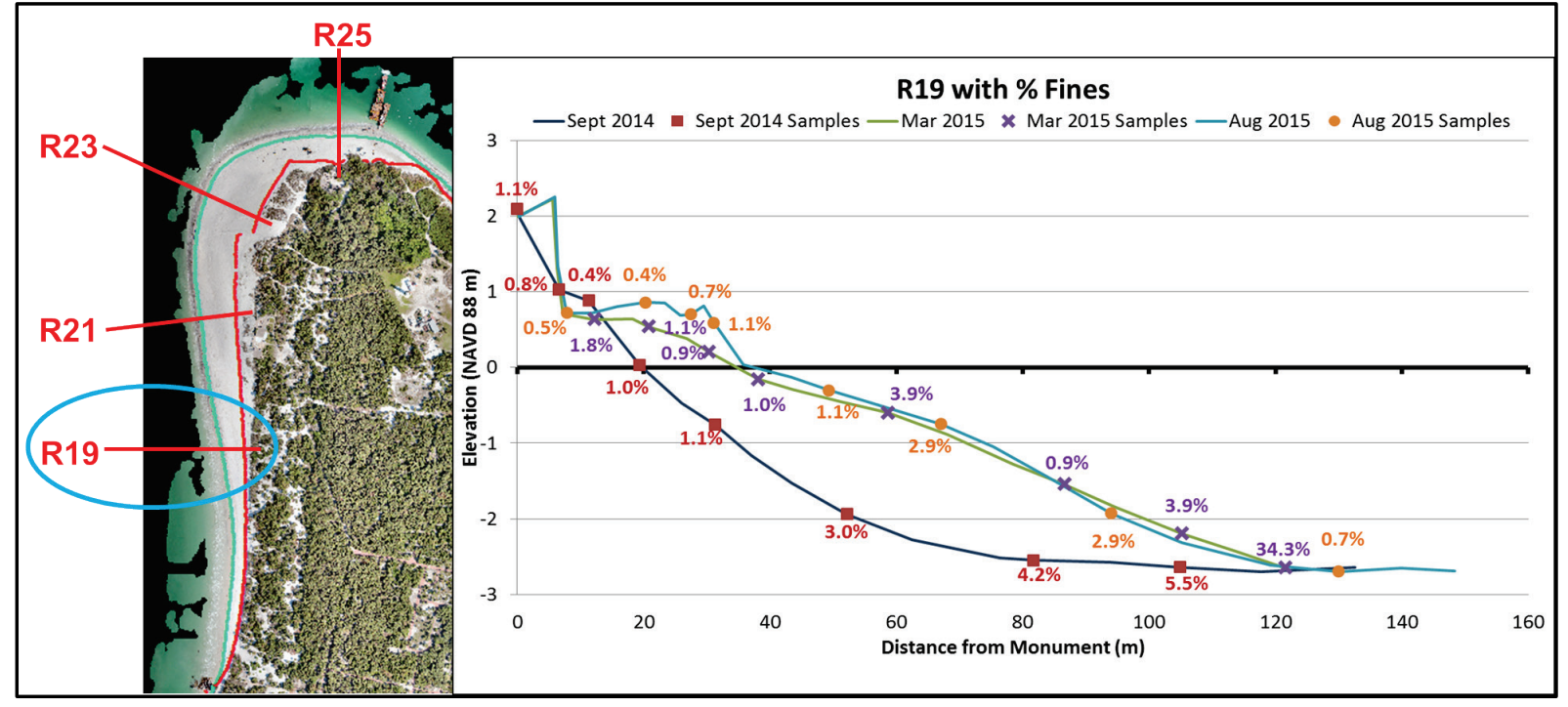

Similar to the traditional nourishment site, the highest concentration of fines at the CSSZ placement was found at the farthest offshore extent of the fill (toe of fill). The toe of fill showed higher fines content at the CSSZ transects $(24.5 \%-83.8 \%)$ compared to the traditional placement. However, by the next sampling event ( 5 months later), the fine sediment content had dropped below 5\% in these areas. In fact, the August 2015 sampling period showed that all surface samples across the dry beach transect contained less than $5 \%$ fine material. 
Figure 16. Profile line R-12 across the point of the CSSZ placement on Egmont Key.

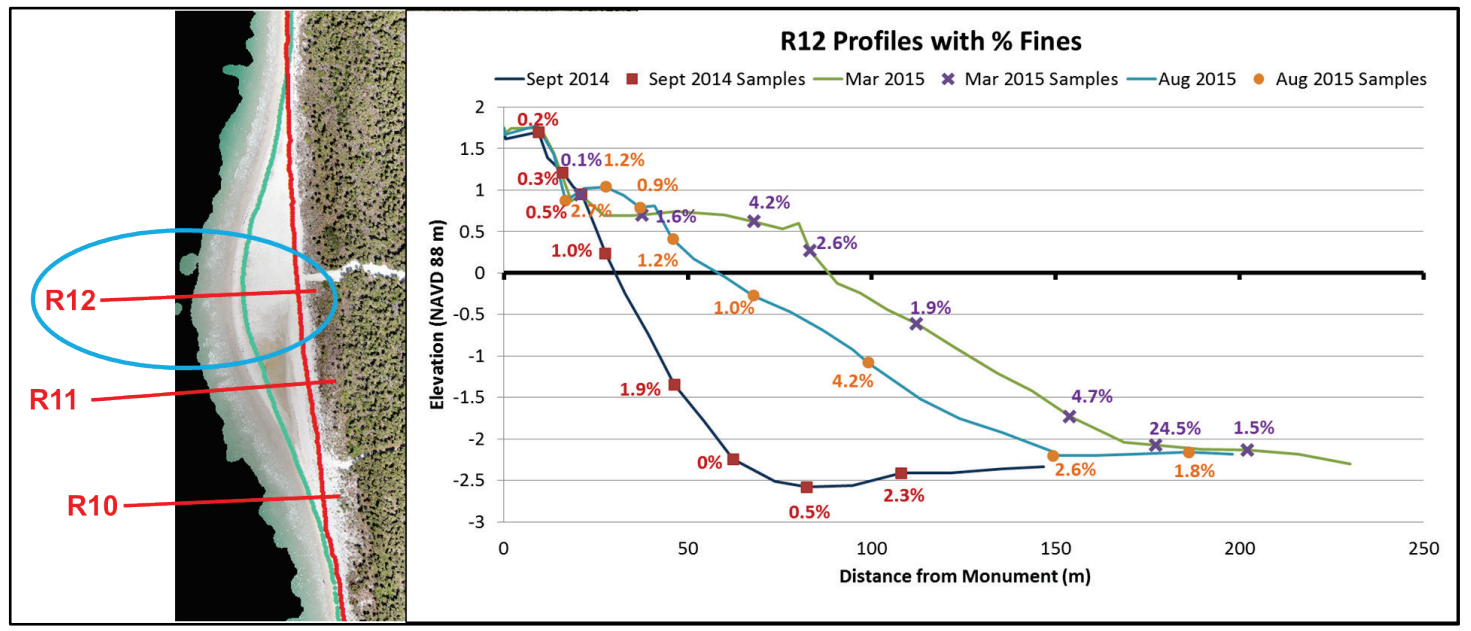

Figure 17. Profile line R-11 moving south along the CSSZ placement area taper on Egmont Key.

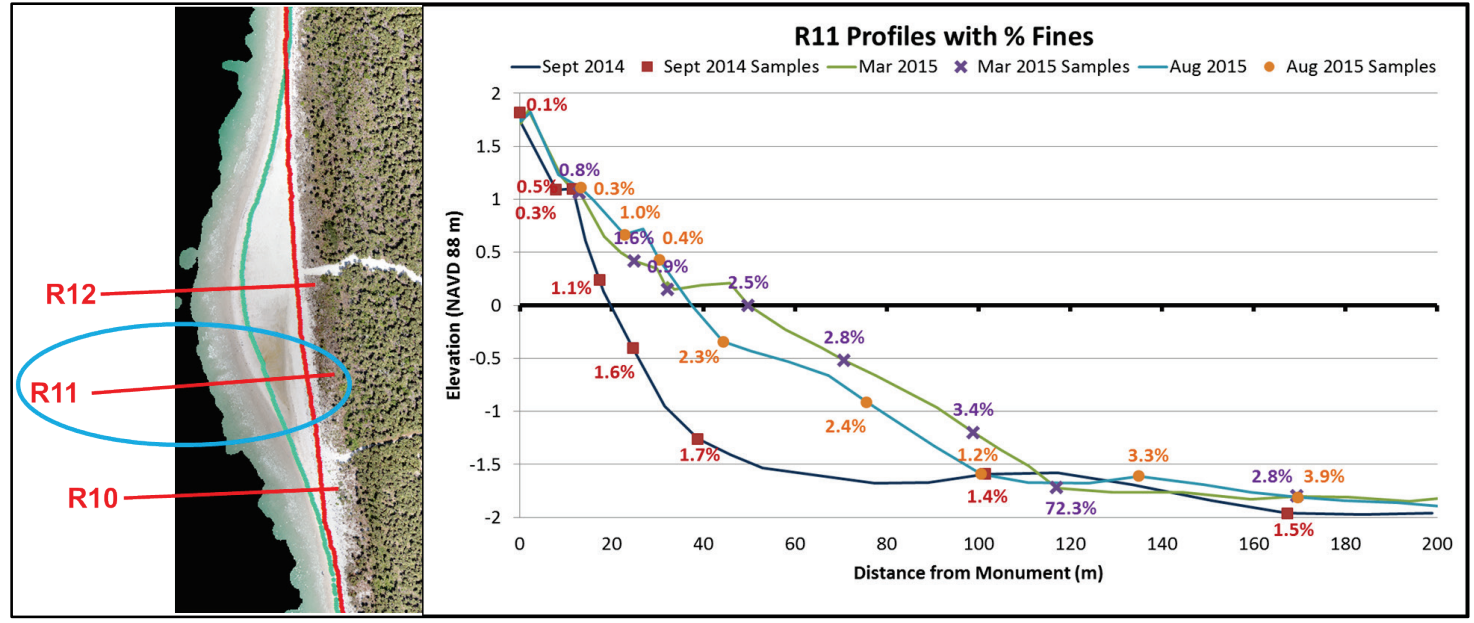

Figure 18. Profile line R10 across the southern most portion of the CSSZ area on Egmont Key.

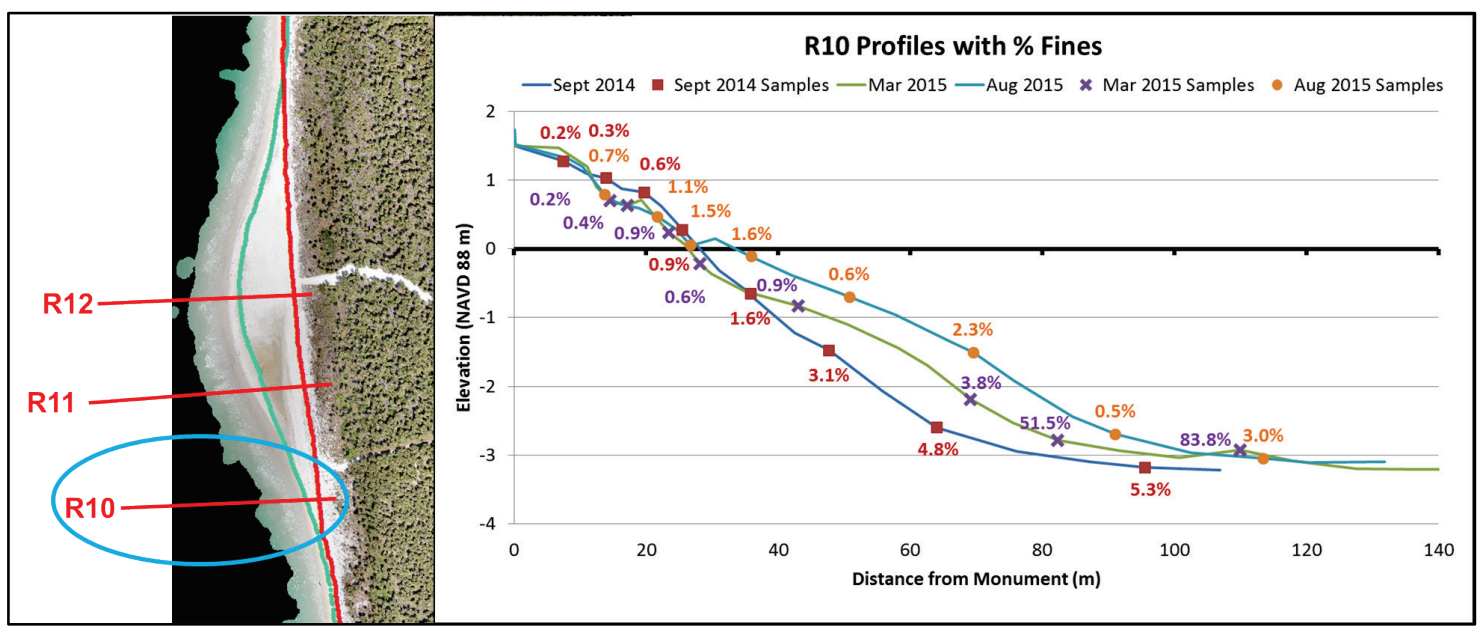




\subsection{Core boring and sediment sample summary}

Sieve analysis showed that the pre-construction beach had $0.7 \%$ fines present and the channel material had over $20.7 \%$ fine material by weight. The composite dry beach samples showed that the dredged and placed material had $1.9 \%$ fines, which was well within the $10 \%$ fines criteria for the beneficial use of channel material allowed by the "Sand Rule." Composite sieve analyses of the surface samples from the postconstruction beaches demonstrated that there was an approximate tenfold decrease in fines percentage from the channel to the final beach placement fill. It is of note that the material used for the CSSZ placement contained a higher percentage of fines than that used for the traditional beach nourishment, which may explain the higher percentage of fines found at the CSSZ nourishment toe.

The in situ channel material was darker (Munsell Value $[\mathrm{MV}]=4.36$ ) than the existing native beach (MV=5.9), likely due to higher content of darker color fines and organic material. Due to fines and organics loss during dredging and placement, composite samples of the post-construction beach was lighter in color value than the parent channel material (MV=5.3). The CSSZ Munsell value was identical to the pre-construction beach while the traditional placement site had a darker value of 5.0. An image referencing the different color values is found in Figure 19.

Figure 19. Example Munsell Color chart for reference (image from http://blog.stephens.edu/arh101glossary/?glossary=value).

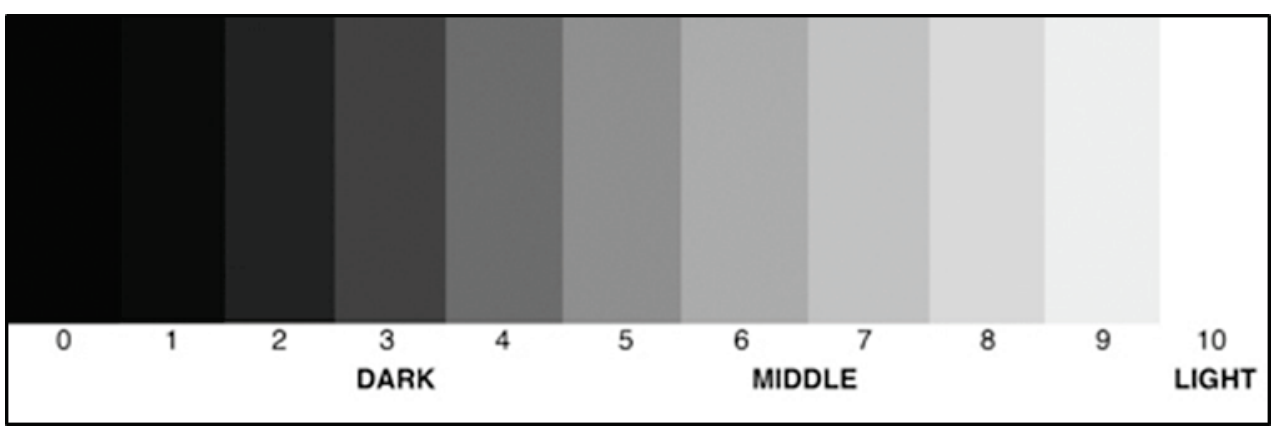




\section{Conclusions}

In November 2014, Tampa Harbor Entrance Channel was dredged, and material was beneficially placed onto Egmont Key. Although the material contained an increased amount of fines according to the State of Florida "Sand Rule," (an average of 20.7\%), an exception was made to allow placement of the sediment directly onto the beach due to the highly erosive nature of the island. Material was placed in a traditional beach nourishment template at the northern portion of the island and in a CSSZ placement approximately $0.8 \mathrm{~km}$ south of that. Core borings and surface sediment samples were collected to quantify fines loss from sediment source to placement site. Based on core borings, the channel contained an average of $\mathbf{2 0 . 7 \%}$ fines with a maximum of over $\mathbf{8 0 \%}$ fines. Surface sediment samples taken from the dry beach pre-construction contained only $0.7 \%$ fines. Post construction, the dry beach contained approximately $1.9 \%$ fines, indicating that although the sediment source contained an increased amount of fines, limited fines ended up on the surface of the dry beach. The resulting nourishment is within the State of Florida "Sand Rule" regulations (i.e., less than $10 \%$ fines are allowable to place onto a beach during a maintenance dredging project). The color of the constructed nourishment sediment was very similar to the preconstruction sediment color in both the traditional beach nourishment and CSSZ placement. 


\section{References}

Brooks, G. R., L. J. Doyle, R. A. Davis, N. T. DeWitt, and B. C. Suthard. 2003. Patterns and controls of surface sediment distribution: West-central Florida inner shelf. Marine Geology 200(1-4): 307-324.

Doyle, L. J., and T. N. Sparks. 1980. Sediments of the Mississippi, Alabama, and Florida (MAFLA) continental shelf. Journal of Sedimentary Research 50(3): 905-915.

Ferguson, T. W., and R. A. Davis. Jr. 2003. Post-Miocene stratigraphy and depositional environments of valley-fill sequences at the mouth of Tampa Bay, Florida. Marine Geology 200(1-4); 157-170.

Folk, R. L., and W. C. Ward. 1957. Brazos River bar: A study in the significance of grain size parameters. Journal of Sedimentary Research 27(1): 3-26.

Galperin, B., A. F. Blumberg, and R. H. Weisberg. 1991. A time-dependent threedimensional model of circulation in Tampa Bay. In Proceedings of the Tampa Bay Area Scientific Information Symposium, Vol. 2, 77-97.

Ginsburg, R. N., and N. P. James. 1974. Holocene carbonate sediments of continental shelves. In The Geology of Continental Margins. Berlin, Heidelberg: Springer.

Goodwin, C. R. 1984. Changes in Tidal Flow, Circulation, and Flushing Caused by Dredge and Fill in Tampa Bay, Florida. Water Supply Paper 2282. No. 84-447. Reston, VA: U.S. Geological Survey.

Hine, A. C. 1997. Structural and paleoceanographic evolution of the margins of the Florida Platform. The Geology of Florida. Gainesville, FL: University Press of Florida.

Hine, A. C., G. R. Brooks, R. A. Davis, D. S. Duncan, S. D. Locker, D. C. Twichell, and G. Gelfenbaum. 2003. The west-central Florida inner shelf and coastal system: A geologic conceptual overview and introduction to the special issue. Marine Geology 200(1): 1-17.

Lewis III, R. R., and E. D. Estevez. 1988. The Ecology of Tampa Bay, Florida: An Estuarine Profile (No. BR-85 (7.18)). Mangrove Systems, Inc., Tampa, FL; Mote Marine Lab., Sarasota, FL.

Loeb, W. A. 1994. Beaches of Pinellas County, Florida; A History of their Comings and Goings (circa 1850-present). No. 94-565. Reston, VA: U.S. Dept. of the Interior, U.S. Geological Survey.

Maglio, C. K., J. D. Ousley, A. G. Hershorin, and M. A. Mora. Tampa harbor maintenance dredging with Egmont key beneficial reuse of high silt content material using a traditional template versus cross shore swash zone placement. In Proceedings of the Western Dredging Association and Texas A\&M University Center for Dredging Studies, "Dredging Summit and Expo 2015." Houston, TX, 22-25 June 2015 .

Munsell Soil Color Charts. 2000. New Windsor, NY: Gretagmacbeth. 
Twenhofel, W. H., and S. A. Tyler. 1941. Methods of Study of Sediments. New York: McGraw-Hill Book Company.

Tyler, Z. J. 2016. Morphodynamics of Egmont Key at the Mouth of Tampa Bay: WestCentral Florida. Master's thesis, University of South Florida.

Wang, P., and R. A. Davis, Jr. 1998. A beach profile model for a barred coast: Case study from Sand Key, West-Central Florida. Journal of Coastal Research 14(3): 981991.

Wang, P., T. M. Beck, and T. M. Roberts. 2011. Modeling regional-scale sediment transport and medium-term morphology change at a dual-inlet system examined with the Coastal Modeling System (CMS): A case study at Johns Pass and Blind Pass, West-central Florida. Journal of Coastal Research 49-60. 


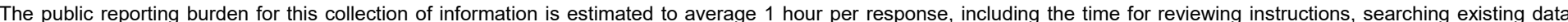

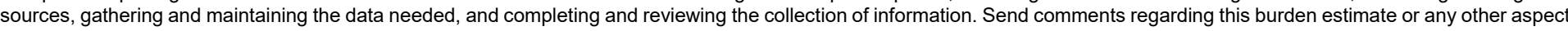

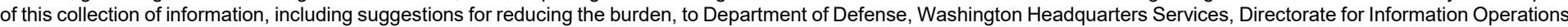

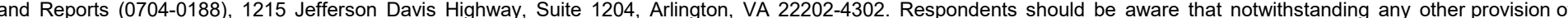
law, no person shall be subject to any penalty for failing to comply with a collection of information if it does not display a currently valid OMB control number.

PLEASE DO NOT RETURN YOUR FORM TO THE ABOVE ADDRESS.

\begin{tabular}{l|l|l}
$\begin{array}{l}\text { 1. REPORT DATE } \\
\text { June } 2019\end{array}$ & $\begin{array}{l}\text { 2. REPORT TYPE } \\
\text { Final Report }\end{array}$ & 3. DATES COVERED (FrOm - To)
\end{tabular}

\section{TITLE AND SUBTITLE}

Beneficial Use of Dredged Material with Increased Fine Sediment Content: A Case Study

at Egmont Key, Florida

5a. CONTRACT NUMBER

5b. GRANT NUMBER

5c. PROGRAM ELEMENT NUMBER

5d. PROJECT NUMBER

456009

5e. TASK NUMBER

5f. WORK UNIT NUMBER

8. PERFORMING ORGANIZATION REPORT NUMBER

ERDC/CHL TR-19-11

10. SPONSOR/MONITOR'S ACRONYM(S)

USACE

\section{SPONSOR/MONITOR'S REPORT} NUMBER(S)

\section{DISTRIBUTION/AVAILABILITY STATEMENT}

Approved for public release; distribution is unlimited.

\section{SUPPLEMENTARY NOTES}

\section{ABSTRACT}

In November 2014, Tampa Harbor Entrance Channel was dredged, and material was placed onto Egmont Key. Although the material contained quantities of fine sediment that were greater than the State of Florida "Sand Rule" criteria, an exception was made to allow placement of the sediment directly onto the beach due to the critically eroding west shoreline of the island. Material was placed in a traditional beach nourishment template at the northern portion of the island and in a cross-shore swash zone placement approximately 0.8 kilometer south of that. Beach profile surveys were collected to document morphology change of the two types of nourishments and to illustrate cross-shore location of each sediment sample. Core borings and surface sediment samples were collected and analyzed to quantify fines loss from sediment source to placement site. Although the core borings taken in the dredging area indicated an average of $20.7 \%$ fines, the surface sediment samples on the dry beach only yielded $1.9 \%$ fines on average, which is within the Florida "Sand Rule" regulation. The post-construction surface sediment samples had a similar color to the pre-construction samples.

\section{SUBJECT TERMS}

Beach nourishment, Dredging, Dredged material, Dredged material-Management, Dredging spoil, Egmont Key (Fla.)

\section{SECURITY CLASSIFICATION OF:}

\begin{tabular}{|l|c|c|c|}
\hline a. REPORT & b. ABSTRACT & c. THIS PAGE & \multirow{2}{*}{ ABSTRACT } \\
Unclassified & Unclassified & Unclassified & SAR
\end{tabular}

18. NUMBER OF 19a. NAME OF RESPONSIBLE PERSON PAGES

34 19b. TELEPHONE NUMBER (Include area code) 601-634-4174 
7. PERFORMING ORGANIZATION NAME(S) AND ADDRESS(ES)

Coastal and Hydraulics Laboratory

U.S. Army Engineer Research and Development Center 3909 Halls Ferry Road

Vicksburg, MS 39180-6199

Galveston District

U.S. Army Corps of Engineers

2000 Fort Point Road

Galveston, TX 77550

Portland District

U.S. Army Corps of Engineers

333 SW 1st Avenue

Portland, OR 97204

University of South Florida

School of Geosciences

4202 E. Fowler Avenue

Tampa, FL 33620 